\title{
Sources of springtime surface black carbon in the Arctic: an adjoint analysis for April 2008
}

\author{
Ling Qi ${ }^{1,2}$, Qinbin $\mathbf{L i}^{1,2}$, Daven K. Henze ${ }^{3}$, Hsien-Liang Tseng ${ }^{1,2}$, and Cenlin $\mathrm{He}^{1,2}$ \\ ${ }^{1}$ Department of Atmospheric and Oceanic Sciences, University of California, Los Angeles, CA, USA \\ ${ }^{2}$ Joint Institute for Regional Earth System Science and Engineering, University of California, \\ Los Angeles, CA, USA \\ ${ }^{3}$ Department of Mechanical Engineering, University of Colorado, Boulder, CO, USA \\ Correspondence to: Ling Qi (qiling@atmos.ucla.edu, qiling0420@gmail.com)
}

Received: 10 December 2016 - Discussion started: 27 February 2017

Revised: 26 May 2017 - Accepted: 11 July 2017 - Published: 15 August 2017

\begin{abstract}
We quantify source contributions to springtime (April 2008) surface black carbon (BC) in the Arctic by interpreting surface observations of $\mathrm{BC}$ at five receptor sites (Denali, Barrow, Alert, Zeppelin, and Summit) using a global chemical transport model (GEOS-Chem) and its adjoint. Contributions to BC at Barrow, Alert, and Zeppelin are dominated by Asian anthropogenic sources (40-43\%) before 18 April and by Siberian open biomass burning emissions (29-41\%) afterward. In contrast, Summit, a mostly free tropospheric site, has predominantly an Asian anthropogenic source contribution (24-68\%, with an average of $45 \%$ ). We compute the adjoint sensitivity of $\mathrm{BC}$ concentrations at the five sites during a pollution episode (20-25 April) to global emissions from 1 March to 25 April. The associated contributions are the combined results of these sensitivities and $\mathrm{BC}$ emissions. Local and regional anthropogenic sources in Alaska are the largest anthropogenic sources of BC at Denali (63\% of total anthropogenic contributions), and natural gas flaring emissions in the western extreme north of Russia (WENR) are the largest anthropogenic sources of $\mathrm{BC}$ at Zeppelin $(26 \%)$ and Alert $(13 \%)$. We find that longrange transport of emissions from Beijing-Tianjin-Hebei (also known as Jing-Jin-Ji), the biggest urbanized region in northern China, contribute significantly $(\sim 10 \%)$ to surface $\mathrm{BC}$ across the Arctic. On average, it takes $\sim 12$ days for Asian anthropogenic emissions and Siberian biomass burning emissions to reach the Arctic lower troposphere, supporting earlier studies. Natural gas flaring emissions from the WENR reach Zeppelin in about a week. We find that episodic transport events dominate BC at Denali (87\%), a site outside
\end{abstract}

the Arctic front, which is a strong transport barrier. The relative contribution of these events to surface $\mathrm{BC}$ within the polar dome is much smaller ( $\sim 50 \%$ at Barrow and Zeppelin and $\sim 10 \%$ at Alert). The large contributions from Asian anthropogenic sources are predominately in the form of "chronic" pollution ( $\sim 40 \%$ at Barrow, $65 \%$ at Alert, and $57 \%$ at Zeppelin) on about a 1-month timescale. As such, it is likely that previous studies using 5- or 10-day trajectory analyses strongly underestimated the contribution from Asia to surface BC in the Arctic.

\section{Introduction}

The Arctic, one of the most sensitive regions to climate change, warms at a rate twice as rapid as the global average (AMAP, 2011). Climate modeling studies indicate that the Arctic surface warms from BC both in the Arctic and over middle latitudes (Bond et al., 2013 and references therein). Specifically, atmospheric black carbon (BC) over lower latitudes warms the Arctic surface $\left(60-90^{\circ} \mathrm{N}\right)$ due to poleward transport of heat absorbed by $\mathrm{BC}\left(0.7-0.8 \mathrm{~K}\left(\mathrm{~W} \mathrm{~m}^{-2}\right)^{-1}\right.$, Shindell and Faluvegi, 2009; Sand et al., 2013, 2015). Although the total effect of $\mathrm{BC}$ in the Arctic troposphere is warming the surface, $\mathrm{BC}$ at different altitudes has different effects on the Arctic surface (Shindell and Faluvegi, 2009; Flanner, 2013). BC in the upper tropospheric Arctic slightly cools $\left(-0.2 \pm 0.1 \mathrm{~K}\left(\mathrm{~W} \mathrm{~m}^{-2}\right)^{-1}\right)$ the Arctic surface due to surface dimming, while surface atmospheric $\mathrm{BC}$ exerts a strong surface warming effect $\left(2.8 \pm 0.5 \mathrm{~K}\left(\mathrm{~W} \mathrm{~m}^{-2}\right)^{-1}\right.$, Flan- 
ner, 2013). In addition, this effect has a strong seasonal variation with the largest mass-normalized Arctic warming in the spring, when the high insolation and surface albedo strongly facilitate a large radiative forcing of $\mathrm{BC}$ and the associated surface warming (Quinn et al., 2008; Flanner, 2013). It is thus imperative to improve our understanding of the distribution of $\mathrm{BC}$ in the springtime in the Arctic and identify the sources both in the troposphere and at the surface.

Numerous studies have analyzed BC vertical profiles and identified sources of springtime $\mathrm{BC}$ in the troposphere in the Arctic (e.g., Liu et al., 2015 and references therein), particularly during polar year 2008. They found that a dense haze layer with maximum BC concentration was usually observed in the middle troposphere (Warneke et al., 2009, 2010; Wang et al., 2011; Brock et al., 2011; Marelle et al., 2015) and their sources were largely diverse. Stohl et al. (2007) found that agricultural fires in eastern Europe strongly enhanced BC concentration in the European Arctic in spring 2006. Studies based on aircraft observations from Arctic Research of the Composition of the Troposphere from Aircraft and Satellites (ARCTAS; Jacob et al., 2010) and Aerosol, Radiation, and Cloud Processes affecting Arctic Climate (ARCPAC; Brock et al., 2011) found that agricultural as well as boreal forest fires in south Siberia dominated BC concentrations (up to $80 \%$ ) in a large part of the Arctic troposphere (particularly in the North American sector) in spring 2008 (Warneke et al., 2009, 2010; Brock et al., 2011; Wang et al., 2011). Given that an increasing trend of frequency of boreal forest fires has been predicted due to global warming, the contribution of these fires to Arctic BC is likely to increase in the future (Soja et al., 2007; Flannigan et al., 2009; Wotton et al., 2010; Liu et al., 2012). With the rapid increase of anthropogenic emissions in eastern and northern Asia, recent studies have shown that this region may become an important source (up to $90 \%$ ) of Arctic BC in late winter and early spring, particularly in the free troposphere (Shaw et al., 2010; Frossard et al., 2011; Liu et al., 2015). Other studies suggested otherwise because strong scavenging during uplift processes in warm conveyer belts can significantly decrease the BC transport efficiency and the resulting contribution from this source (Stohl, 2006; Matsui et al., 2011).

The Arctic surface is isolated from the free troposphere by a strong transport barrier, the so-called "Arctic front", which is a closed dome formed by surfaces of constant potential temperature (Stohl, 2006 and references therein). As such, the Arctic front strongly reduces the influence from episodic pollution entering the Arctic in the middle and upper troposphere and limits their impact on surface BC concentrations (Stohl, 2006; Brock et al., 2011). In addition, emissions within the polar dome are trapped in the lower troposphere and enhance surface concentration. The Arctic front extends further south $\left(40^{\circ} \mathrm{N}\right)$ over Europe and Russia in winter and early spring (Stohl, 2006). Thus, sources of Arctic surface $\mathrm{BC}$ have been repeatedly identified as emissions from the two regions. A large fraction of the 5- or 10-day back trajecto- ries ends in the industrial regions in Russia and Europe (Pollisar et al., 2001; Sharma et al., 2006; Huang et al., 2010a; Dutkiewicz et al., 2014). In addition, long-term observations (decades) at surface sites Barrow (Pollisar et al., 2001; Sharma et al., 2006; Hirdman et al., 2010), Alert (Sharma et al., 2004, 2006; Huang et al., 2010a; Hirdman et al., 2010), Zeppelin (Eleftheriadis et al., 2009; Hirdman et al., 2010), and Kevo (Dutkiewicz et al., 2014) showed that BC concentration has steadily declined since 1980 . They related these declining trends with declining emissions in the former Soviet Union. Asian contributions to surface $\mathrm{BC}$ were considered not to be significant due to two reasons. First, very few back trajectories ended in this region (Pollisar et al., 2001; Sharma et al., 2006; Huang et al., 2010; Dutkiewicz et al., 2014). Second, observed atmospheric surface $B C$ concentrations at Alert, Barrow, and Zeppelin did not increase with increasing BC emissions in east Asia since 2000 (Sharma et al., 2013). In addition, most of these studies identified sources of $\mathrm{BC}$ in the Arctic on the timescale of seasons and contrasted sources in winter and in summer. Few studies have identified sources of $\mathrm{BC}$ in the springtime surface Arctic, which efficiently warm the Arctic surface (Flanner, 2013).

Previous studies on BC source apportionment have used either statistical analysis of trajectories (Pollisar et al., 2001; Sharma et al., 2004; Eleftheriadis et al., 2009; Stohl, 2006; Hirdman et al., 2010; Harrigan et al., 2011, Dutkiewicz et al., 2014), the tagged tracer technique (Wang et al., 2011, 2014), or sensitivity simulations with perturbed emissions (Koch and Hansen, 2005; Shindell et al., 2008; Huang et al., 2010a; Bourgeois and Bey, 2011; Sharma et al., 2013; Ma et al., 2013). Trajectory analysis efficiently identifies transport pathways, but the model integration error increases when modeling time exceeds 5-6 days. This error introduces large uncertainties to the back-trajectory paths; thereby, sources can only be reliably assigned on continental scales (Liu et al., 2015). In addition, the assumption of the trajectory method is that the tracer is inert and not affected by chemical or other removal processes, which introduce large uncertainties to source apportionment (Liu et al., 2015). Tagged tracer and sensitivity simulations include chemical and physical processing of BC but are computationally limited in the source region numbers that can be considered (Wang et al., 2014). The chemical transport model (CTM) adjoint not only explicitly simulates chemical and physical processes of aerosols but also offers a far more computationally efficient approach for receptor-oriented source attribution (Henze et al., 2007; Hakami et al., 2007). A single run of the adjoint model can compute the sensitivity of $\mathrm{BC}$ concentrations at a given location (or an average over a spatial domain) and time (or an average in a time interval) to global emissions over the spatial and temporal resolution of the model (e.g., at $2^{\circ}$ latitude $\times 2.5^{\circ}$ longitude horizontal resolution and $1 \mathrm{~h}$ temporal resolution; L. Zhang et al., 2009). The method has been applied to examine trans-Pacific (L. Zhang et al., 2009) and Arctic (Walker et al., 2012) transport of ozone, source ap- 
portionment of aerosol pollution episodes (Nester and Panitz, 2006; L. Zhang et al., 2015a), and BC radiative forcing in the Himalayas and Tibetan Plateau (Kopacz et al., 2011). Yet, the quality of an adjoint analysis depends on the accuracy of the physical representations built into the forward version of the model.

In a previous study (Qi et al., 2017a), we assessed the sensitivity of BC concentration in surface air and in snow in the Arctic to flaring emissions, dry deposition velocity over snow and ice, and Wegener-Bergeron-Findeisen (WBF) in mixed-phase clouds. With all the improvements, simulated $\mathrm{BC}$ concentrations in snow in eight Arctic subregions agree with observations within a factor of 2 ; meanwhile, simulated surface atmospheric BC falls within the range of observations. Based on this improved simulation of $\mathrm{BC}$ distribution in the Arctic, we use here the tagged tracer technique in a global 3-D chemical transport model, GEOS-Chem, to identify sources of BC at Arctic surface sites (Denali, Barrow, Alert, Zeppelin, and Summit) resolved at continental scales in April 2008. We then use the GEOS-Chem adjoint to refine the estimated contributions to $\mathrm{BC}$ at the five sites from sources resolved at the $2^{\circ}$ latitude $\times 2.5^{\circ}$ longitude horizontal scale and hourly temporal resolution during a pollution event (20-25 April).

\section{Surface BC observations}

In situ measurements of $\mathrm{BC}$ are available at five sites within the Arctic Circle (Fig. 1): Denali, AL, USA (63.7 N, $149.0^{\circ} \mathrm{W} ; 0.66 \mathrm{~km}$ above mean sea level, a.s.l.) in the low Arctic; three sites in the high Arctic, Barrow, AL, USA $\left(71.3^{\circ} \mathrm{N}, 156.6^{\circ} \mathrm{W} ; 11 \mathrm{~m}\right.$ a.s.l.), Alert, Canada $\left(82.3^{\circ} \mathrm{N}\right.$, $62.3^{\circ} \mathrm{W} ; 210 \mathrm{~m}$ a.s.1.), and Zeppelin, Norway $\left(79^{\circ} \mathrm{N}, 12^{\circ} \mathrm{E}\right.$; $478 \mathrm{~m}$ a.s.l.); and a free tropospheric site at Summit, Greenland $\left(72.6^{\circ} \mathrm{N}, 38.5^{\circ} \mathrm{W} ; 3.22 \mathrm{~km}\right.$ a.s.1.). Denali, outside the Arctic front $\left(\sim 66^{\circ} \mathrm{N}\right)$, receives pollution transported to the Arctic via the "Aleutian storm track" displaced to the central and north Alaska in April 2008 (Fuelberg et al., 2010). Barrow and Alert are within the polar dome and experience regular temperature inversion (Sharma et al., 2013). This inversion strongly suppresses the vertical transport from above and traps emissions within the polar dome in the lower troposphere (Stohl, 2006; Brock et al., 2011). The Barrow site is on the northern land tip of Alaska, $8 \mathrm{~km}$ northeast of the town of Barrow. It is influenced by both marine and continental air (Hirdman et al., 2010). Alert, located the furthest north of all five sites, is most isolated from continental sources (Hirdman et al., 2010). The Zeppelin observatory is on a mountain ridge on the Svalbard archipelago. Because of the relatively high elevation (478 m), Zeppelin is not always in a stable inversion layer (Sharma et al., 2013). Summit $(3.2 \mathrm{~km})$, on the top of the Greenland glacial ice sheet, is always in the Arctic free troposphere (Hirdman et al., 2010). BC is measured by the thermal optical reflectance combustion method at De-

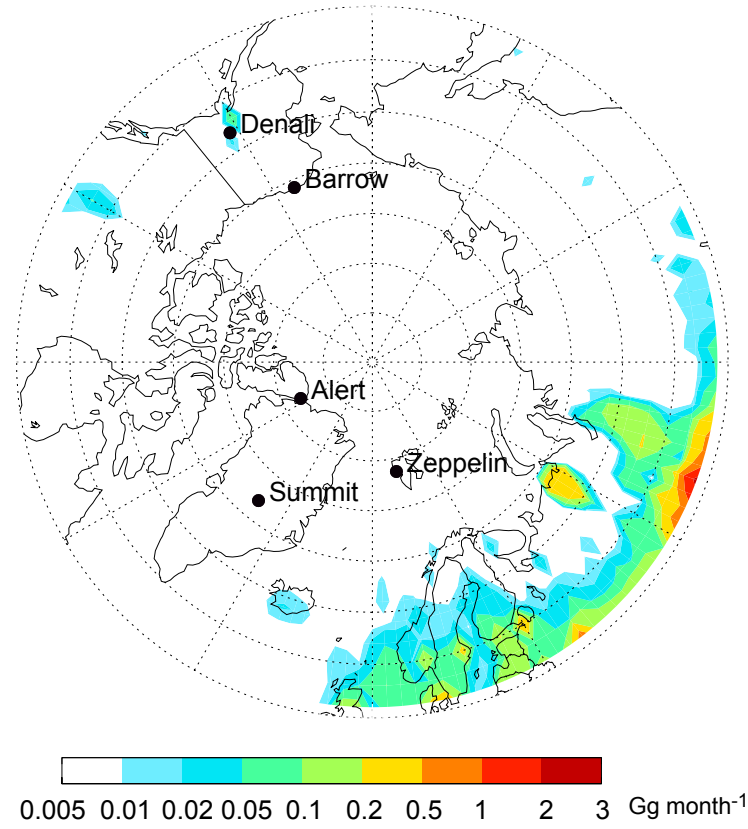

Figure 1. BC emissions (Gg month $\left.{ }^{-1}\right)$ in the Arctic for April. Solid circles are the surface sites: Denali, AL, USA $\left(63.7^{\circ} \mathrm{N}\right.$, $149.0^{\circ} \mathrm{W}$; $0.66 \mathrm{~km}$ a.s.1.), Barrow, AL, USA $\left(71.3^{\circ} \mathrm{N}, 156.6^{\circ} \mathrm{W}\right.$; $0.01 \mathrm{~km}$ a.s.1.), Alert, Canada $\left(82.3^{\circ} \mathrm{N}, 62.3^{\circ} \mathrm{W} ; 0.21 \mathrm{~km}\right.$ a.s.1.), Summit, Greenland $\left(72.6^{\circ} \mathrm{N}, 38.5^{\circ} \mathrm{W} ; 3.22 \mathrm{~km}\right.$ a.s.1.), and Zeppelin, Norway $\left(79^{\circ} \mathrm{N}, 12^{\circ} \mathrm{E} ; 0.47 \mathrm{~km}\right.$ a.s.l.). Data are from Bond et al. (2007) and natural gas flaring emissions from Stohl et al. (2013).

nali, by a particle soot absorption photometer at Barrow, and by an aethalometer at Alert, Zeppelin, and Summit. Uncertainties of these measurements lie in overestimation of absorption based on light transmission, which is also affected by scattering. Additionally, empirical conversion from optical response to BC mass also involves uncertainties. Finally, there are uncertainties from non-BC absorbers. Details are summarized in Qi et al. (2017a).

\section{GEOS-Chem and its adjoint}

\subsection{GEOS-Chem simulation of BC}

GEOS-Chem is a global CTM driven with assimilated meteorology from the Goddard Earth Observing System (GEOS) of the NASA Global Modeling and Assimilation Office (GMAO). We use the GEOS-5 meteorological data set to drive model simulation at $2^{\circ}$ latitude $\times 2.5^{\circ}$ longitude horizontal resolution and 47 vertical layers from the surface to $0.01 \mathrm{hPa}$. Tracer advection, moist convection, deep convection, and shallow convection schemes are summarized in Qi et al. (2017a).

Northern Hemisphere BC emissions in April are shown in Fig. 2. Anthropogenic emissions of $\mathrm{BC}$ are from Bond et al. (2007) with Asian emissions from Q. Zhang et 
Table 1. Atmospheric lifetimes $(\tau)$ of Arctic BC (2008) from major sources and source regions and BC emissions in these regions.

\begin{tabular}{|c|c|c|c|c|c|c|c|c|c|}
\hline & & \multicolumn{2}{|c|}{ Emissions $(\mathrm{Gg})$} & \multicolumn{6}{|c|}{$\tau^{*}$ (days) } \\
\hline & & \multirow[t]{2}{*}{ Annual } & \multirow[t]{2}{*}{ March-April } & \multicolumn{3}{|c|}{ Annual } & \multicolumn{3}{|c|}{ March-April } \\
\hline & & & & $\tau$ & $\tau_{\text {dep. }}$ & $\tau_{\text {tran }}$ & $\tau$ & $\tau_{\text {dep }}$ & $\tau_{\text {tran }}$ \\
\hline \multirow[t]{4}{*}{ Anthropogenic } & North America & 420 & 69 & 9 & 22 & 14 & 12 & 36 & 18 \\
\hline & Europe & 648 & 107 & 6 & 9 & 17 & 9 & 16 & 21 \\
\hline & Siberia & 108 & 18 & 5 & 7 & 23 & 7 & 10 & 28 \\
\hline & Asia & 3588 & 591 & 9 & 47 & 11 & 12 & 71 & 14 \\
\hline \multirow[t]{2}{*}{ Biomass burning } & Siberia & 289 & 125 & 9 & 16 & 19 & 12 & 30 & 21 \\
\hline & South Asia & 203 & 113 & 9 & 98 & 9 & 9 & 141 & 10 \\
\hline
\end{tabular}

* Assume changing of total mass of $\mathrm{BC}$ in the Arctic $(Q)$ is negligible during the periods we study. Sources of $\mathrm{BC}$ in the Arctic are balanced by its sinks. The sources include $\mathrm{BC}$ emissions in the Arctic and northward transport of $\mathrm{BC}$ at $60^{\circ} \mathrm{N}$ during the whole period, and the sinks are $\mathrm{BC}$ removal (dry and wet deposition) in the Arctic $(R)$ and southward transport of $\mathrm{BC}$ at $60^{\circ} \mathrm{N}\left(F_{\text {out }}\right)$. Thus, the lifetime of $\mathrm{BC}(\tau)$ in the Arctic is estimated as $\tau=\frac{Q}{F_{\mathrm{out}}+R}=\frac{Q}{F_{\mathrm{in}}+E}$ where $Q$ is BC mass in the Arctic $(\mathrm{kg}), F_{\mathrm{out}}$ and $F_{\text {in }}$ southward and northward mass flux of BC at $60^{\circ} \mathrm{N}\left(\mathrm{kg} \mathrm{day}^{-1}\right), R$ the removal mass flux of $\mathrm{BC}$, and $E$ the emission rate of $\mathrm{BC}$ in the Arctic $\left(>60^{\circ} \mathrm{N}, \mathrm{kg} \mathrm{day}^{-1}\right)$. BC lifetime against deposition $\left(\tau_{\mathrm{dep}}\right)$ is estimated as $\tau_{\mathrm{dep}}=\frac{Q}{R}$. BC lifetime against transport $\left(\tau_{\text {tran }}\right)$ is estimated as $\tau_{\text {tran }}=\frac{Q}{F_{\text {out }}}$.

al. (2009). The resulting global anthropogenic emissions are $5.8 \mathrm{Tg} \mathrm{yr}^{-1}$. We apply seasonal variation for domestic heating emissions, which are concentrated in winter at high latitudes, based on the heating degree-day concept (Stohl et al., 2013). We also include emissions from gas flares in the oil and natural gas industry completely from Stohl et al. (2013). Gas flaring emissions only account for $3 \%$ of global total BC emissions but they account for $42 \%$ of total BC emissions in the Arctic. They are significant contributors to both $\mathrm{BC}$ deposition $(\sim 20 \%)$ and ambient $\mathrm{BC}$ concentrations during the snow season (September to April) in the Arctic (Qi et al., 2017a). Open biomass burning emissions are available from the Global Fire Emissions Database version 3.1 (GFED3) with updates for small fire emissions (Randerson et al., 2012). We use the GFED3 inventory with two temporal resolutions: the standard monthly inventory and a 3hourly inventory. We use the monthly inventory for the standard simulation and the 3-hourly inventory for the uncertainty simulation (Sect. 4.3.1), because we found that the monthly inventory produces a lower root mean square error against both the aircraft and surface BC observations in the Arctic. To derive the 3-hourly inventory, daily emissions are first resampled temporally from the monthly inventory according to Moderate Resolution Imaging Spectroradiometer (MODIS) daily active fire counts (Giglio et al., 2003). Then, a diurnal cycle with a 3-hourly time step based on the active fire observations (Prins et al., 1998; Mu et al., 2011) is applied to the daily inventory. The resulting 3-hourly inventory has the same overall emissions as the monthly inventory but with a much finer temporal distribution. This finer resolution provides more information of the temporal variations of BC emissions, yet it also introduces uncertainties associated with the detailed temporal distribution. $\mathrm{BC}$ emissions in major source regions are shown in Table 1. BC emissions in the Arctic are shown in Fig. 1.

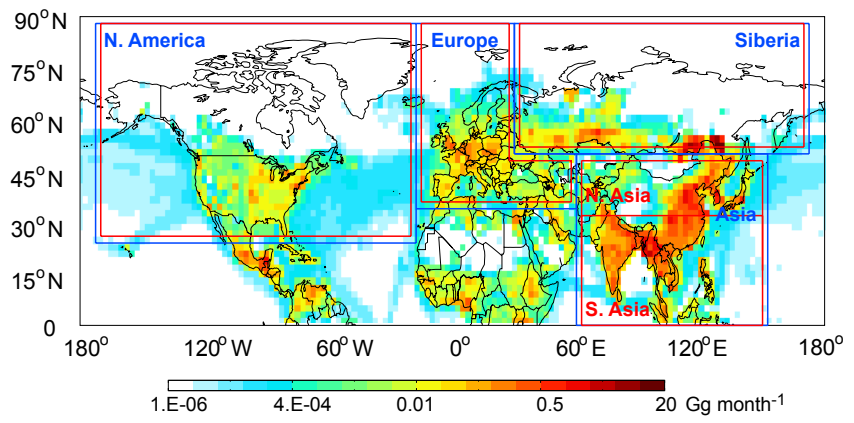

Figure 2. Northern Hemisphere BC emissions for April $\left(\mathrm{Gg}\right.$ month $\left.^{-1}\right)$. BC tracers are "tagged" by four anthropogenic (blue rectangles) and five biomass burning sources (red rectangles): North America $\left(172.5-17.5^{\circ} \mathrm{W}, 24-88^{\circ} \mathrm{N}\right)$ - both anthropogenic and biomass burning; Europe $\left(17.5^{\circ} \mathrm{W}-30^{\circ} \mathrm{E}, 33-88^{\circ} \mathrm{N}\right.$ and 30 $\left.60^{\circ} \mathrm{E}, 33-50^{\circ} \mathrm{N}\right)$ - both; Siberia $\left(30-172.5^{\circ} \mathrm{E}, 50-88^{\circ} \mathrm{N}\right)$ - both; Asia $\left(60-152.5^{\circ} \mathrm{E}, 0-50^{\circ} \mathrm{N}\right)$ - anthropogenic; northern China (60$\left.152.5^{\circ} \mathrm{E}, 30-50^{\circ} \mathrm{N}\right)$ - biomass burning sources; South Asia and Southern China $\left(60-152.5^{\circ} \mathrm{E}, 0-30^{\circ} \mathrm{N}\right)$ - biomass burning.

We assume $80 \%$ of the freshly emitted BC particles are hydrophobic and become hydrophilic with an $e$-folding time of 1.15 days, which reproduces the Asian outflow (Park et al., 2003, 2005). Liu et al. (2011) implemented an OH-dependent aging scheme, which has a strong diurnal and seasonal variation. Slower aging in winter allows more BC to remain hydrophobic and be transported to the Arctic, resulting in a better comparison with surface observations. The change in other seasons is insignificant. We implemented this aging scheme in GEOS-Chem and also found insignificant change of tropospheric and surface BC concentration in the Arctic in April (see the Supplement Fig. S1). Thus, we use the 1.15 days $e$-folding aging time in this study. We estimate dry deposition velocity of $\mathrm{BC}$ over snow and ice us- 
ing the resistance-in-series method (Wesely, 1989; Zhang et al., 2001), validated by recent measurements of aerosol dry deposition velocity over snow and ice (Qi et al., 2017a). Wet scavenging of BC follows Wang et al. (2011) with updates for BC scavenging efficiency in mixed-phase clouds (Qi et al., 2017b). We parameterize BC scavenging efficiency in mixedphase clouds accounting for the effects of the WBF process (Qi et al., 2017b). WBF occurs when environmental vapor pressure is above the saturation vapor pressure of ice crystals and below that of cold water drops. Ice crystals grow and cold water drops evaporate, releasing BC particles in the cold water drops back into interstitial air. This process strongly reduces $\mathrm{BC}$ scavenging efficiency globally (from $8 \%$ in the tropics to $76 \%$ in the Arctic), slows down wet scavenging, and increases atmospheric BC loading. Including WBF significantly improves the simulation of $\mathrm{BC}$ distribution in air (discrepancy reduced from -65 to $30 \%$ ) and in snow (discrepancy is halved both in midlatitudes from 34 to $17 \%$, and in the Arctic from -20 to $-10 \%$ ) globally (Qi et al., 2017b). We test the uncertainties of source attribution associated with WBF in Sect. 4.3.2.

We identify sources of BC in the Arctic in April 2008 using the tagged tracer technique, which is a physically consistent and computationally efficient approach to attribute sources resolved at continental scales (Wang et al., 2011, 2014). BC emitted from different source types (anthropogenic versus open biomass burning emissions) and source regions (Europe, Siberia, Asia, and North America) is tagged with no overlap among these geographical regions (Fig. 2). $\mathrm{BC}$ emitted in these tagged regions is explicitly tracked in the model and treated the same way (transport, chemical, and physical processes) as the original $\mathrm{BC}$, allowing for direct estimate of the contributions from individual tagged source types and source regions. We spin up the model by 2 months before the starting date of 1 March.

Arctic BC vertical profiles and sources at different altitudes in April 2008 (polar year) have been studied intensively (Brock et al., 2011; Wang et al., 2011). We identify sources of $\mathrm{BC}$ at the Arctic surface in this study during this period to complete the picture. In April 2008, the polar anticyclone was located near its climatological position. However, the Aleutian storm track was displaced north of its typical position, causing North Pacific cyclones to pass over north or central Alaska, instead of the more typical route over the Gulf of Alaska (Fuelberg et al., 2010). This departure from climatology suggests that the poleward transport of emissions from Eurasia was facilitated. In contrast, the negative North Atlantic Oscillation in April 2008 was associated with a diminished transport of pollution from North America to the Arctic. Thus, the contribution to surface BC in the Arctic from Eurasia in April 2008 is probably biased high compared to the climatology, while the contribution from North America is biased low. In addition, the agricultural and forest fires in south Russia in April 2008 were much larger and earlier than normal, resulting in a much larger than normal contribution from this region to $\mathrm{BC}$ in the surface Arctic.

\subsection{GEOS-Chem adjoint simulation of $\mathrm{BC}$}

Compared with the tagged tracer technique, the adjoint modeling approach computes source-receptor sensitivities for individual receptor locations more efficiently and can be done at a much finer temporal and spatial resolution. We use GEOS-Chem adjoint (Henze et al., 2007) model v35 with updated emissions, dry deposition velocity, and wet scavenging as described in Sect. 3.1. The adjoint model has previously been used to constrain emissions of CO (Kopacz et al., 2009, 2010), BC (Mao et al., 2014; Zhang et al., 2015b), and other aerosols (Henze et al., 2009) and to identify sources of ozone (L. Zhang et al., 2009), BC (Kopacz et al., 2011), and other aerosols (Zhang et al., 2015a). In addition, the adjoint has also been used to estimate the sensitivity of direct radiative forcing to aerosol emissions (Henze et al., 2012).

In this study, we use the adjoint model to compute the sensitivity of $\mathrm{BC}$ concentrations $\left([\mathrm{BC}]_{\mathrm{s}}\right)$ at the five receptor sites in the Arctic to global $\mathrm{BC}$ emissions $(e)$ resolved at $2^{\circ}$ latitude $\times 2.5^{\circ}$ longitude horizontal resolution over the history of air parcels reaching the Arctic surface at these sites (1 March-25 April). This sensitivity is denoted as $k$ :

$[\mathrm{BC}]_{\mathrm{s}}=k \times e$.

As horizontal advection in GEOS-Chem is approximately linear, and the rest of the chemical and physical process are entirely linear with respect to emissions, multiplication of the sensitivity $(k)$ by emissions $(e)$ yields an estimate of how much $\mathrm{BC}$ emissions from each grid cell contribute to $\mathrm{BC}$ concentrations at a receptor site $\left([\mathrm{BC}]_{\mathrm{S}}\right.$ ) (Henze et al., 2007; Kopacz et al., 2011). In this study, $[\mathrm{BC}]_{\mathrm{s}}$ is the mean BC concentration at each receptor site (Fig. 1) during 2025 April 2008. The sensitivity is propagated backwards in time from 25 April to 1 March. Then, hourly contributions from each grid cell can be calculated by multiplying these sensitivities with emissions at that time. Integrating these contributions from 1 March to 25 April gives the contributions of emissions in each grid cell to $[\mathrm{BC}]_{\mathrm{s}}$ at the receptor sites. Further integrating these contributions globally approximates the mean $[\mathrm{BC}]_{\mathrm{S}}$ during 20-25 April at each site.

We validate GEOS-Chem adjoint via comparison of adjoint gradients to forward model sensitivities, $\Lambda$, calculated using the finite difference approximation:

$\Lambda=\frac{J(\sigma+\delta \sigma)-J(\sigma)}{\delta \sigma}$,

where $J$ is the cost function, defined as the mean $[\mathrm{BC}]_{\mathrm{s}}$ at each of the five receptor sites and $\sigma$ the scaling factor for $\mathrm{BC}$ emissions ( $\sigma=1$ for the sensitivity simulation). We use $\delta \sigma=0.1$ for all tests in this study. We compare the sensitivities of mean $[\mathrm{BC}]_{\mathrm{S}}$ during 20-25 April at each receptor site to anthropogenic and biomass burning emissions during 
1 March-25 April estimated by the finite difference and adjoint method. This evaluation is quite time consuming to perform at each grid cell throughout the globe due to the expense of the finite difference calculations $(144 \times 91$ runs $)$. Hence, we select 10 model grid cells with the largest anthropogenic and open biomass burning sources for the validation, because the absolute difference between the two methods is more substantial for larger values (Henze et al., 2007).

Figure 3 shows the adjoint validation results. The simulation is for 1 March-25 April and the cost function $J$ is evaluated at the end of each simulation. The agreement between finite difference sensitivities and the adjoint gradients are within $\sim 15 \%$ (slopes vary from 0.84 to 1.15 , except for biomass burning contribution at Summit), largely within the uncertainty that arises from deriving the adjoint of the advection using the continuous approach despite there being nonlinearities in the discrete treatment of advection in the forward model (Henze et al., 2007). To quantify the discrepancy, we compare the sensitivities estimated by finite difference and the adjoint method at one grid cell in biomass burning regions in Siberia, with advection turned on and off. Without advection, finite difference sensitivities agree with adjoint gradients to within $1 \%$. However, with advection turned on, the difference increases to $\sim 15 \%$. Long-range transport from source regions to receptor sites in the Arctic does not exaggerate the disagreement. In addition, simulation lengths of 1, 5, 10, 20, and 50 days are not found to substantially alter the overall comparison, indicating that this error does not accumulate over time. In addition, the adjoint gradients estimated by the continuous advection scheme are likely smoother and more physically meaningful than the finite difference sensitivities estimated by the discrete advection scheme (Henze et al., 2007; Liu and Sandu, 2008; Gou et al., 2011). For example, a negative value of finite difference sensitivity is shown for anthropogenic sources for Denali and an abnormally low finite difference sensitivity value is also shown for anthropogenic sources for Barrow, because of the discrete advection scheme used in the forward model (Thuburn and Haine, 2001; Henze et al., 2007; Hakami et al., 2007).

\section{Results and discussion}

\subsection{Sources of Arctic BC in April 2008}

\subsubsection{Sources contributing to $\mathrm{BC}$ at selected surface sites}

Figure 4a shows measured and GEOS-Chem-simulated daily mean BC concentrations at the five sites for April 2008. At Denali, the model reproduces both the monthly mean (within $26 \%$ ) and the day-to-day variation (correlation coefficient $r=0.96)$. At Barrow and Alert, simulated monthly mean BC concentrations agree with observations to within $10 \%$. At
Zeppelin, the monthly mean BC is overestimated by $80 \%$. This positive bias is likely due to two reasons. First, the gas flaring emissions, the major sources of $\mathrm{BC}$ at Zeppelin, are probably too high because the emission factor used is much larger than recent field and lab measurements (Stohl et al., 2013; Qi et al., 2017a). Second, the model underestimates $\mathrm{BC}$ scavenging efficiency at Zeppelin, where riming dominates the in-cloud scavenging in mixed-phase clouds (Qi et al., 2017a). At Summit, a free tropospheric site, monthly mean $\mathrm{BC}$ concentration is overestimated by $60 \%$.

Using tagged tracers, we compute the contribution from major continental-scale source regions (Fig. 2) to surface BC in the Arctic (Fig. 4b). Asian anthropogenic sources make the largest contribution to surface BC (e.g., 32-35\% at Barrow, Alert, and Zeppelin) and free tropospheric BC (45\% at Summit) in the Arctic. Other large anthropogenic sources are from North America (at Denali and Barrow) and Siberia (at Zeppelin) because of their close proximity. Anthropogenic contributions from Europe, Siberia, and North America to $\mathrm{BC}$ at Alert are comparable.

We also find that Asian anthropogenic contribution sharply increases (doubles or triples) from January-March (not shown) to April across the five sites, although BC emissions in Asia are much lower in April than in the previous 3 months (by $25 \%$ ) due to less energy consumption from domestic heating. In contrast, contributions from European, North American, and Siberian anthropogenic sources are relatively flat from January-March to April. Such contrast indicates that the poleward transport of Asian emissions in April is enhanced so much that it offsets the relatively lower emissions in that month. Previous studies suggest that Asian emissions are probably underestimated (Fu et al., 2012; Zhang et al., 2015a) by about a factor of 2. If the actual Asian emissions were higher, Asian contribution to the Arctic is likely larger than estimates in this study. Additionally, given that Asian BC emission is likely to continue to rise over the coming years (Qin and Xie, 2011; Wang et al., 2012), it is likely that their contribution to springtime $\mathrm{BC}$ in the Arctic will likewise increase.

Observations show a strong enhancement of $\mathrm{BC}$ concentration at Denali (up to $\sim 400 \mathrm{ng} \mathrm{m}^{-3}$ ) during 18-30 April (Fig. 4, top left). GEOS-Chem reproduces this strong transport event (to within $20 \%$ ). This enhancement is from a strong increase of contribution from North American anthropogenic sources (up to $\sim 200 \mathrm{ng} \mathrm{m}^{-3}$ ) and Siberian biomass burning emissions (up to $\sim 200 \mathrm{ng} \mathrm{m}^{-3}$ ) (Fig. 4, top right) due to favorable meteorological conditions over the North Pacific for poleward transport (Sect. 4.2.1). The Siberian biomass burning emissions are from forest fires in the southern Siberia-Lake Baikal area and agricultural burning in Kazakhstan-southern Russia (Warneke et al., 2009, 2010; Wang et al., 2011). These biomass burning emissions also enhance $\mathrm{BC}$ concentrations at the other four sites, although with much smaller magnitudes (up to $\sim 60 \mathrm{ng} \mathrm{m}^{-3}$ ) and at different times. At Denali, the contribution of Siberian biomass 

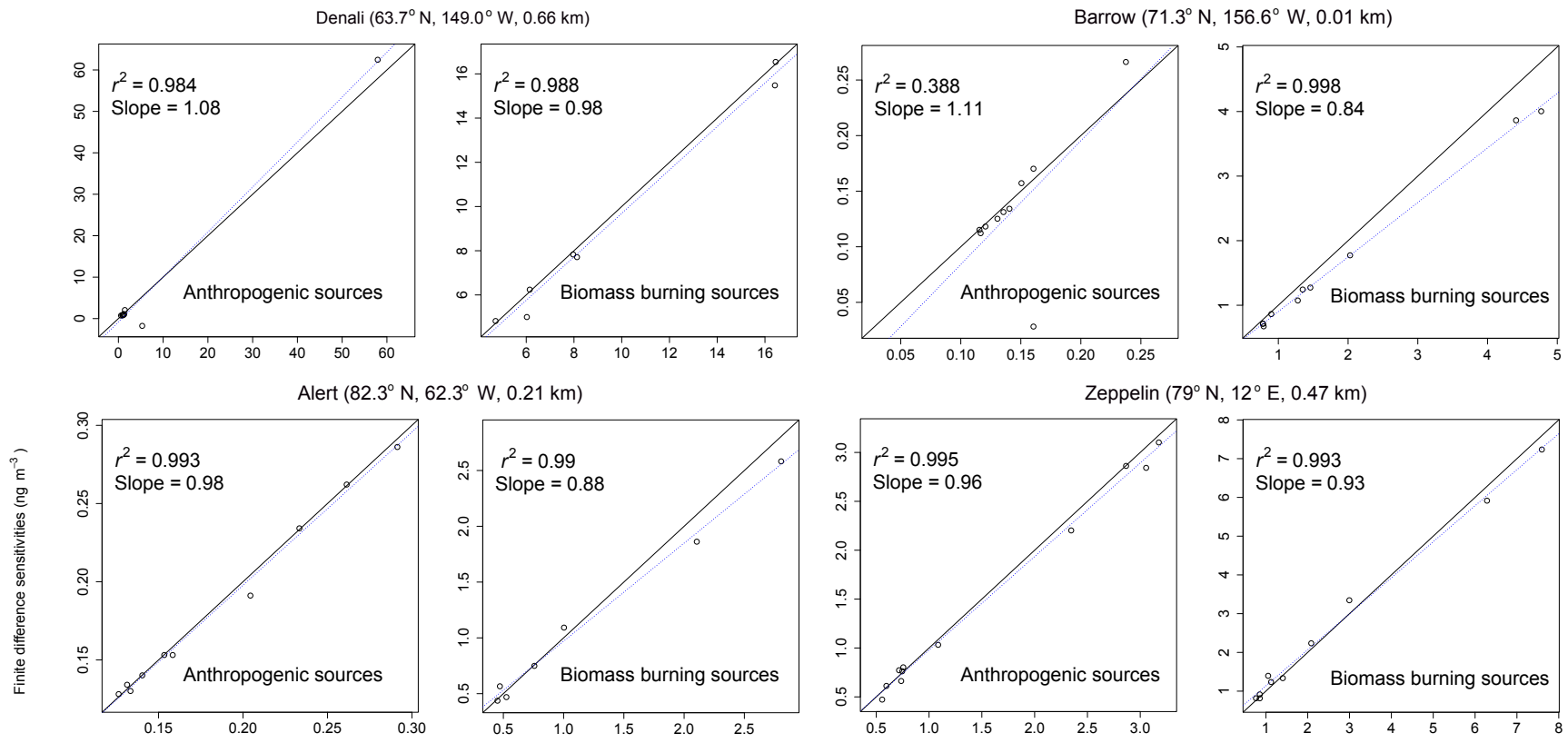

Summit $\left(72.6^{\circ} \mathrm{N}, 38.5^{\circ} \mathrm{W}, 3.22 \mathrm{~km}\right)$

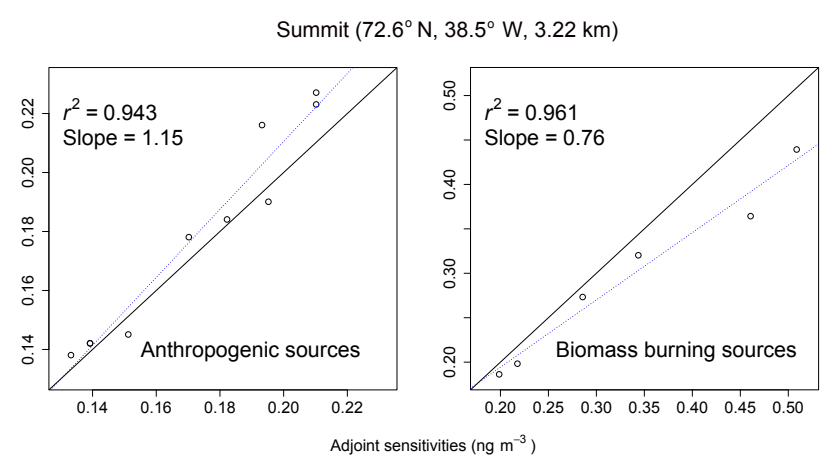

Adjoint sensitivities $\left(\mathrm{ng} \mathrm{m}^{-3}\right)$

Figure 3. GEOS-Chem adjoint versus finite difference gradients of BC concentration for 10 model grid cells with largest anthropogenic BC contributions and 10 grid cells with largest biomass burning BC contributions at Denali, Barrow, Alert, Zeppelin, and Summit (see Fig. 1). Values are for 1 March-25 April 2008. Regression lines, slopes, and $r^{2}$ values are shown.

burning reaches its maximum during 18-25 April. At Barrow, two maxima appear on 18 and 24 April. At Alert and Summit, the Siberian biomass burning contributions are the largest during 25-30 April. At Zeppelin, the two peaks appear on 22 and 30 April. The relative contributions from biomass burning emissions to $\mathrm{BC}$ at the five sites reach up to $46-64 \%$, exceeding the contribution from anthropogenic sources during the pollution event. Yttri et al. (2014) derived $\mathrm{BC}$ contribution from biomass burning at Zeppelin based on the ratio of levoglucosan and BC in 2008. They found that the lower and upper estimates of biomass burning contributed $\mathrm{BC}$ at Zeppelin were $4.3-13.3$ and $31-45 \%$. This estimate is broadly consistent with the range from this study (5.2-55.1\% with a mean of $17.6 \%$ ). It indicates that ways to mitigate open biomass burning can be effective at reducing springtime surface BC in the Arctic and thus lessen the BC snow albedo effect (Flanner, 2013).

\subsubsection{Atmospheric lifetimes of Arctic BC}

Using tagged tracers (Sect. 3.1), we show GEOS-Chemsimulated transport pathways of Arctic BC in April 2008 from major sources (Fig. 2) in Figs. S2 and S3. These transport pathways are in broad agreements with previously identified pathways of $\mathrm{BC}$ reaching the Arctic surface (Hirdman et al., 2010; Dutkiewicz et al., 2014) and the troposphere (e.g., Klonecki et al., 2003; Stohl, 2006; Wang et al., 2014). For instance, anthropogenic emissions from Siberia and Europe are transported to the Arctic through low-level transport (Klonecki et al., 2003; Stohl, 2006; Harrigan et al., 2011; Marelle et al., 2015), while anthropogenic emissions from Asia and biomass burning emissions from south Asia are uplifted in source regions and enter the Arctic through the middle and upper troposphere (Matsui et al., 2011; Wang et al., 2014; Liu et al., 2015). These transport pathways result in considerably different lifetimes of Arctic BC against deposi- 


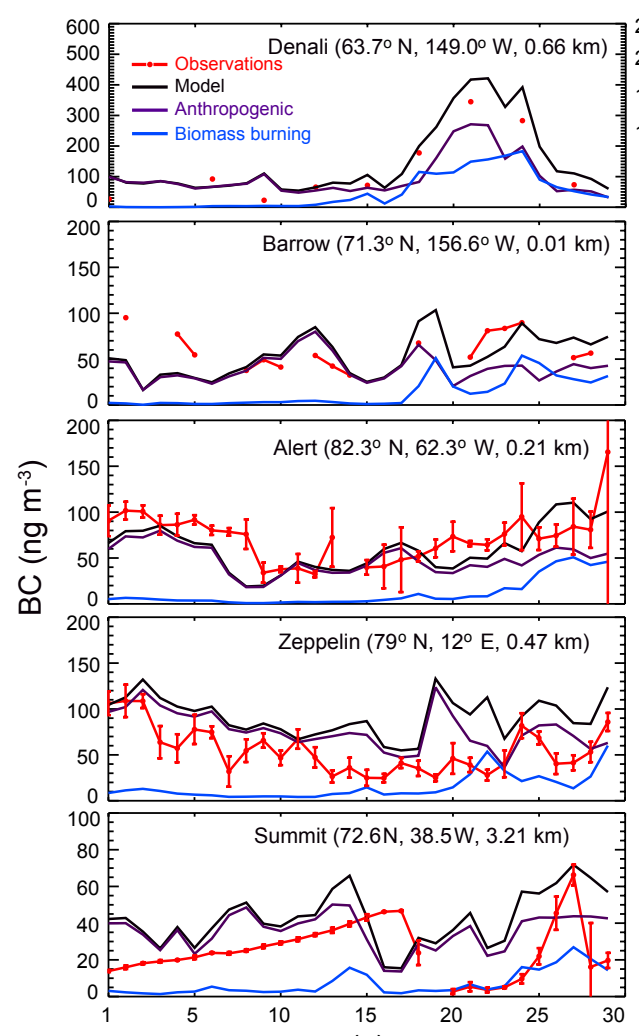

(a)
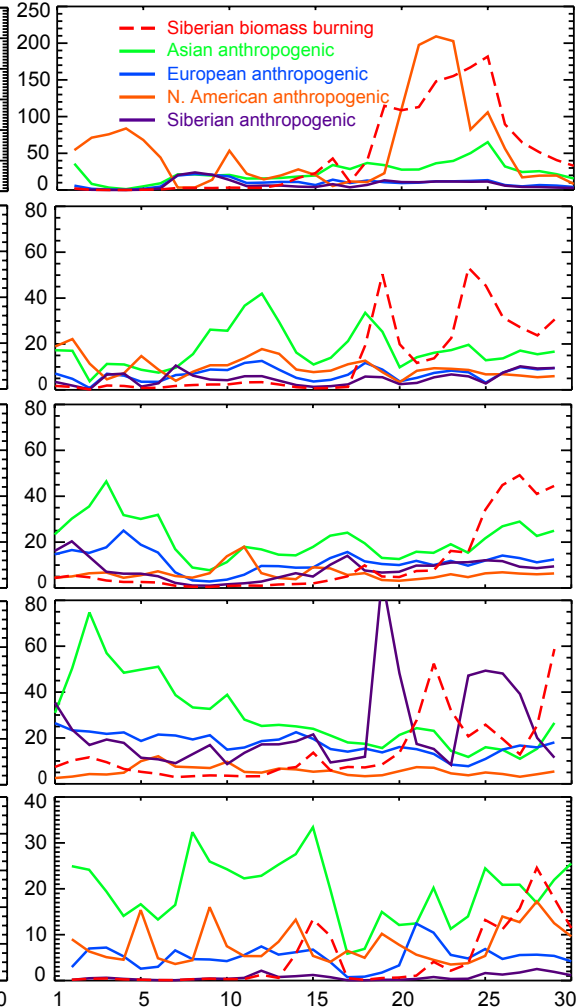

(b)

Figure 4. (a) Observed (red lines) and GEOS-Chem-simulated (black lines) daily mean BC concentrations at Denali, Barrow, Alert, Zeppelin, and Summit (see Fig. 1) for April 2008. Bars are standard deviations of observations. Modeled BC concentrations are decomposed into contributions from anthropogenic (purple lines) and biomass burning emissions (blue lines). Panel (b) indicates the major contributions: Siberian biomass burning (red dashed line), Asian anthropogenic (green solid line), European anthropogenic (blue solid line), North American anthropogenic (orange solid line), and Siberian anthropogenic (purple solid line) sources.

tion and transport (Table 1). For example, BC from Europe and Siberia enters the Arctic through the lower troposphere where it experiences relatively fast dry and wet deposition (Bourgeois and Bey, 2011; Wang et al., 2014). Consequently, the lifetimes against deposition are relatively short (7-9 days annually; 10-16 days for March-April). In contrast, BC from Asian anthropogenic and south Asian biomass burning emissions is transported into the Arctic middle and upper troposphere where deposition is relatively weak. As expected, the resulting lifetimes against deposition are much longer ( $\sim 1.5-3$ months annually and $\sim 2-4$ months for MarchApril). The lifetimes against deposition of BC from North American anthropogenic sources and Siberian biomass burning sources fall somewhere in between (2-3 weeks annually and $\sim 1$ month for March-April). In contrast, the lifetime of $\mathrm{BC}$ against transport is much shorter in the upper troposphere than that in the lower troposphere because of the larger southward wind and the associated southward BC flux in the upper troposphere. For instance, the lifetime of $\mathrm{BC}$ against transport for south Asian biomass burning emissions (10 days) is much shorter than BC from European (21 days) and Siberian (28 days) anthropogenic sources, supporting previous stud- ies (Stohl, 2006 and references thereafter). Thus, BC lifetime in the Arctic is determined by deposition and transport in the lower troposphere and is dominated by transport in the middle and upper troposphere. Combining the two removal processes, $\mathrm{BC}$ in the middle tropospheric Arctic has the longest lifetimes. As shown in Table 1, North American and Asian anthropogenic sources and Siberian biomass burning sources, which enter the Arctic in the middle troposphere, have the longest lifetimes (12 days in March and April). In addition, BC lifetimes in March and April are up to 3 days longer than the annual ones, driven by the slow deposition due to the dry and stable atmosphere in March and April. Longer lifetimes of $\mathrm{BC}$ from the three sources in March and April indicate that they have more persistent effects on $\mathrm{BC}$ concentration and distribution in the springtime Arctic than the other sources and in other seasons.

\subsection{Adjoint source attribution of Arctic BC during 20-25 April 2008}

The tagged tracer technique can identify sources of BC efficiently at large geographical (e.g., continental) scales (see 


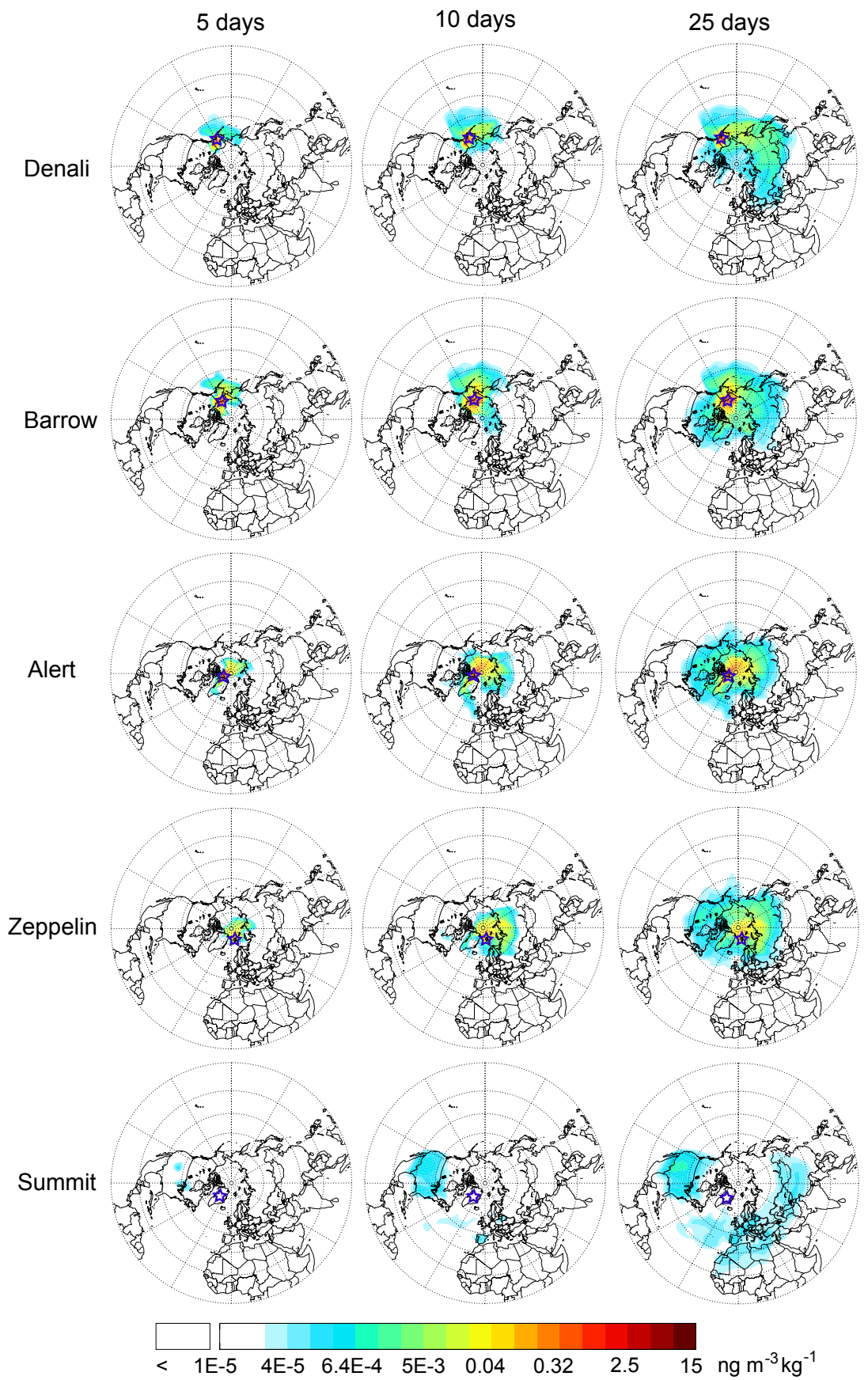

Figure 5. Sensitivity of mean BC concentration (averages for 20-25 April 2008) at Denali, Barrow, Alert, Zeppelin, and Summit (see Fig. 1) to Northern Hemisphere hypothetical unit BC emissions from during the 5, 10, and 25 days prior to 25 April. See text for details.

Sect. 4.1). However, for episodic transport, source attribution at much finer spatial and temporal resolution is often needed. In this section, we focus our analysis on the strong pollution event during 20-25 April most notably at Denali (Fig. 4). We use the GEOS-Chem adjoint to estimate sources of BC at all five sites at $2^{\circ}$ latitude $\times 2.5^{\circ}$ longitude horizontal and hourly temporal resolution.

\subsubsection{Sensitivity of surface Arctic BC to the Northern Hemisphere emissions}

Figure 5 shows the sensitivity of mean BC during 20 25 April at the five surface sites to emissions in the Northern Hemisphere during the last 5, 10, and 25 days (dates back from 25 April) of transport. The sensitivities are computed per model grid cell using results from the adjoint simulations 
(Sect. 3.2) and integrated in the given time periods $(5,10$, or 25 days). BC at the four surface sites is most sensitive to nearby sources within 5 to 10 days prior to reaching these sites. When integrated over the 25 days prior to arrival, Denali, outside the Arctic front, is most exposed to emissions in the Bering Sea and Russia. Barrow, Alert, and Zeppelin in the high Arctic are most sensitive to emissions within the polar dome. More specifically, BC at Barrow, Alert, and Zeppelin is most sensitive to emissions in North America, the North Pole, and Europe, respectively. Our estimates are consistent with sensitivity patterns of the transport climatologies (2000-2007) in winter from Hirdman et al. (2010) for the three sites. The sensitivity of BC at Summit is clearly different from the other four low-level surface sites. BC at Summit in the free troposphere is more sensitive to emissions at lower than at higher latitudes, consistent with a previous study (Hirdman et al., 2010). Because of its higher altitude, Summit $(3.2 \mathrm{~km})$, more than the other four Arctic surface sites, is frequently exposed to air parcels from warmer low latitudes that rise isentropically and transported northwards (Hirdman et al., 2010). In addition, Summit is more sensitive to emissions from the United States but relatively less sensitive to Eurasian emissions than the other four surface sites. Emissions within the polar dome do not influence BC concentration at Summit because the stable atmosphere within the polar dome during the simulation period in this study strongly suppresses the vertical transport of emissions from the surface to the free troposphere. The difference of sensitivities for Summit between this study and Hirdman et al. (2010) is that this study does not show a strong sensitivity to emissions over Greenland, where the highest sensitivity is shown in Hirdman et al. (2010). This difference probably resulted from different seasons and years simulated in the two studies (this study: 20-25 April 2008; Hirdman et al. (2010): climatology (2000-2007) in winter and summer).

\subsubsection{Source attribution of surface Arctic BC based on adjoint sensitivity}

Figure 6 shows contributions from global $\mathrm{BC}$ emissions during 1 March-25 April to BC concentrations during 2025 April at Denali, Barrow, Alert, Zeppelin, and Summit as computed from the GEOS-Chem adjoint simulations (Sect. 3.2). Figure 6a shows the contributions integrated from 1 March to 25 April. Figure 6b shows hourly contributions from major source regions (as defined in Fig. 2) during 1 March-25 April. The left panels are BC concentrations which originated from each model grid cell subsequently transported to the receptor sites. Summing these values up globally approximates (within $15 \%$; see Sect. 3.2) the mean forward-simulated BC concentrations during 20-25 April at the receptor sites. Summing up these values in a specific region (e.g., regions defined in Fig. 2), i.e., integrating the area underneath an individual curve (Fig. 6b), gives the overall contribution from $\mathrm{BC}$ emitted in that source region dur- ing 1 March-25 April. The results are summarized in Table 2 . The difference between this adjoint attribution and the tagged tracer method is within $15 \%$ (Table 2). Such a difference is largely explained by the choices of discrete (in the forward simulation) versus continuous (in the adjoint derivation) treatment of advection (Sect. 3.2). Transport timescales from different sources to the five sites can also be inferred from the spectra in the right panels.

Previous studies found that boreal forest fires in the southern Siberia-Lake Baikal area $\left(40-60^{\circ} \mathrm{N}, 100-140^{\circ} \mathrm{E}\right)$ and grass/crop burning in Kazakhstan-southern Russia (40$60^{\circ} \mathrm{N}, 30-90^{\circ} \mathrm{E}$ ) were the major sources of $\mathrm{BC}$ sampled along the ARCPAC and ARCTAS flights in April 2008 based on MODIS fire detection (Warneke et al., 2009, 2010). We aggregate separately the contributions from forest fires and grass/crop burning to $\mathrm{BC}$ at the five receptor sites. The resulting adjoint sensitivity-based estimates show that Siberian biomass burning contributions at the five sites are predominantly $(>90 \%)$ from forest fires in the southern SiberiaLake Baikal area. Forest fires in that region during 1-14 April have large influences on BC at the two Alaskan sites (Denali and Barrow), reaching these two sites after 11-25 days of transport (Fig. 6b). The contribution from those forest fires, when integrated during 1-14 April, is 4 times larger at Denali $\left(137.8 \mathrm{ng} \mathrm{m}^{-3}\right)$ than at Barrow $\left(30.4 \mathrm{ng} \mathrm{m}^{-3}\right)$. Note the different $y$-axis ranges (Fig. 6b). The contributions at Alert and Zeppelin show similar temporal distributions, with relatively large influences from emissions during 1-6 and 7-12 April but different intensities. The contribution is a factor of 3 higher at Zeppelin $\left(39.3 \mathrm{ng} \mathrm{m}^{-3}\right)$ than at Alert $\left(14.3 \mathrm{ng} \mathrm{m}^{-3}\right)$.

In contrast, global anthropogenic contributions are considerably more scattered. At Denali, for instance, local and regional emissions from power plants (such as the North Pole; US EIA, 2010) and petroleum refinery industries near Fairbanks (US EIA, 2016) account for $63 \%$ of total global anthropogenic contribution to BC at Denali. Additionally, we find that the two sites are influenced by long-range transport of emissions from northeast China, particularly residential emissions from Heilongjiang province. $\mathrm{BC}$ emissions from natural gas flares in the WENR are significant sources of BC in the Arctic (Stohl et al., 2013; Qi et al., 2017a). These flares are the largest sources of BC at Alert $(13 \%$ of the global anthropogenic contributions) and Zeppelin (26\% of global anthropogenic contributions). Global contributions to $\mathrm{BC}$ at Summit are distributed more evenly geographically compared to the other four sites. An interesting feature of the anthropogenic contributions is that industrial and residential BC emissions from the Jing-Jin-Ji cluster of megacities and the Shandong province in east China (together, they encompass six model grid cells) are common important sources (7-10\% of global contributions) of BC at all five sites.

At Denali, and to a much lesser degree at Barrow, significant contributions are seen from Asian anthropogenic BC emissions during 8-15 April, with a maximum contribution from emissions on 11 April. These emissions arrive at 

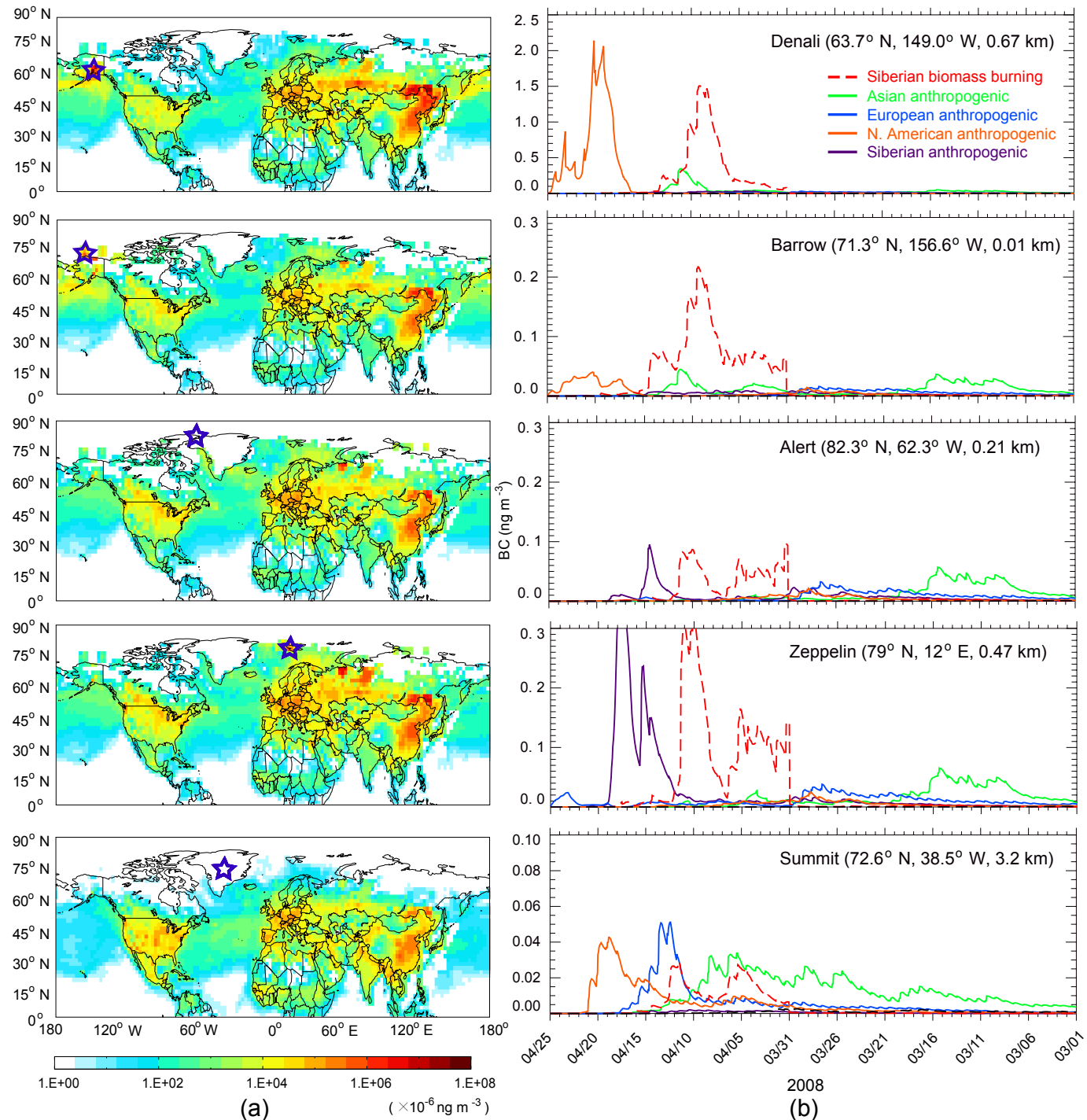

(b)

Figure 6. GEOS-Chem-simulated contributions to BC concentrations, averaged over 20-25 April 2008, at (stars, a) Denali, AL, USA $\left(63.7^{\circ} \mathrm{N}, 149.0^{\circ} \mathrm{W}\right.$; 0.66 km a.s.1.), Barrow, AL, USA (71.3 ${ }^{\circ} \mathrm{N}, 156.6^{\circ} \mathrm{W} ; 10 \mathrm{~m}$ a.s.1.), Alert, Canada $\left(82.3^{\circ} \mathrm{N}, 62.3^{\circ} \mathrm{W} ; 2^{210} \mathrm{~m}\right.$ a.s.1.), Zeppelin, Norway $\left(79^{\circ} \mathrm{N}, 12^{\circ} \mathrm{E} ; 470 \mathrm{~m}\right.$ a.s.1.), and Summit, Greenland $\left(72.6^{\circ} \mathrm{N}, 38.5^{\circ} \mathrm{W} ; 3.22 \mathrm{~km}\right.$ a.s.1.), from Northern Hemisphere emissions as computed from adjoint simulations (see Sect. 3.2 for details): (a) cumulative contributions from 1 March to 25 April and (b) timedependent contributions from Siberian biomass burning (red dashed line), Asian anthropogenic (solid green line), European anthropogenic (solid blue), North American anthropogenic (solid orange), and Siberian anthropogenic sources (solid purple). Source regions are as defined in Fig. 2.

the sites after 12-17 days of transport. This episode results from "direct" transport from Asia to the two sites (Brock et al., 2011 and references therein). The transport timescales are broadly consistent with previous estimates. For example, using a trajectory model coupled with tracer emissions, Stohl (2006) showed that, of the air parcels from Asia transported to the Arctic in winter, $25 \%$ arrived in less than 14 days and $50 \%$ in more than 20 days. Harrigan et al. (2011) attributed BC sampled along a 12 April 2008 DC-8 flight during the ARCTAS field campaign (Jacob et al., 2010) to Asian emissions $10-15$ days prior to sampling times. At Denali,
Barrow, Alert, and Zeppelin, all four low-level sites, model results show persistent influences from Asian anthropogenic emissions of BC, emitted as far back as 6-16 March, after journeys of 35-50 days of transport, presumably after being transported to the Arctic circle and entrained by and becoming part of the circumpolar transport around and within the Arctic circle (Ma et al., 2013). These long timescales are born out by the long transport time from Asia to the Arctic (12-17 days) and the long lifetime in the Arctic afterward (12 days; Table 1). In addition, this lifetime of 12 days is estimated using the average deposition and southward flux 
Table 2. Model-simulated relative contributions to surface BC concentration (ng m ${ }^{-3}$ ) at selected Arctic sites (Fig. 1) for 20-25* April 2008.

\begin{tabular}{|c|c|c|c|c|c|c|c|c|c|}
\hline & & \multicolumn{4}{|c|}{ Anthropogenic } & \multicolumn{2}{|c|}{ Biomass burning } & \multirow[t]{2}{*}{ Total } & \multirow{2}{*}{$\begin{array}{l}\text { Adjoint } \\
\text { Forward }\end{array}$} \\
\hline & & Asia & Siberia & Europe & N.A. & Siberia & S. Asia & & \\
\hline \multirow[t]{2}{*}{ Denali } & Forward & 41.9 & 10.4 & 11.1 & 142.4 & 142.4 & 0.33 & 352.1 & \\
\hline & Adjoint & 38.3 & 9.5 & 10.0 & 146.0 & 137.8 & 0.26 & 341.9 & $97 \%$ \\
\hline \multirow[t]{2}{*}{ Barrow } & Forward & 15.0 & 4.4 & 5.9 & 7.6 & 27.8 & 0.15 & 60.1 & \\
\hline & Adjoint & 13.6 & 4.3 & 5.5 & 7.4 & 30.4 & 0.11 & 61.8 & $103 \%$ \\
\hline \multirow[t]{2}{*}{ Alert } & Forward & 16.6 & 10.1 & 10.8 & 4.7 & 14.3 & 0.25 & 58.5 & \\
\hline & Adjoint & 13.8 & 9.5 & 9.3 & 4.5 & 14.3 & 0.15 & 51.8 & $89 \%$ \\
\hline \multirow[t]{2}{*}{ Zeppelin } & Forward & 21.0 & 32.8 & 14.6 & 5.7 & 39.3 & 0.35 & 116.5 & \\
\hline & Adjoint & 17.8 & 32.4 & 13.4 & 5.3 & 39.3 & 0.23 & 108.8 & $93 \%$ \\
\hline \multirow[t]{2}{*}{ Summit } & Forward & 17.2 & 0.8 & 7.5 & 6.1 & 5.9 & 1.15 & 42.0 & \\
\hline & Adjoint & 14.3 & 0.7 & 7.1 & 7.2 & 4.8 & 1.13 & 38.0 & $90 \%$ \\
\hline
\end{tabular}

* Values are averages for 20-25 April. "Forward" and "adjoint" are from "tagged tracer" and from adjoint simulations. See text for details.

in March and April. For specific air parcels (e.g., air parcels during 6-16 March), they might experience slower deposition and lower southward flux and reside in the atmosphere for a longer time, resulting in a more persistent influence on surface BC in the Arctic. Direct, episodic transport of Asian emissions during 8-15 April account for $66 \%$ of the total Asian contribution (from emissions during 1 March25 April) to $\mathrm{BC}$ at Denali and $37 \%$ at Barrow. In contrast, Asian emissions during 6-16 March and the subsequent circumpolar transport (hence chronic pollution; Brock et al., 2011) account for $39 \%$ of the total Asian contribution to BC at Barrow, $65 \%$ at Alert, and $57 \%$ at Zeppelin. These results suggest that both direct, episodic events and chronic Asian anthropogenic pollution, on timescales of 1-2 months, play comparable roles in enhancing springtime Arctic surface BC. Previous studies identifying sources of Arctic surface BC used 5- or 10-day back-trajectory analyses (Pollisar et al., 2001; Sharma et al., 2004; Eleftheriadis et al., 2009; Huang et al., 2010a; Matsui et al., 2011; Dutkiewicz et al., 2014). As such, the relatively short timescales used in those studies likely result in significant underestimates of long-range transport of BC from Asia to the Arctic.

At Denali, North American emissions have nearly an immediate impact, on a timescale of 0-9 days, because of the proximity to regional sources (power plants and petroleum refinery industries) in Alaska. These episodic transport events are the major parts of North American contributions at Denali $(98 \%)$ and to a much lesser degree at Barrow (64\%). There are secondary maxima in the North American anthropogenic contributions during 16-31 March (a time lag of 20-30 days) at Denali and Barrow. These maxima reflect circumpolar transport of North American sources from Canada and the lower 48 states (hence the longer time lags). At Alert and Zeppelin, no direct transport events from
North American anthropogenic sources are seen. Instead, circumpolar transport dominates the contribution from North American anthropogenic sources, which account for $\sim 9 \%$ of total BC at Alert and $\sim 5 \%$ at Zeppelin. At Denali, Barrow, Alert, and Zeppelin, there is no direct transport from European anthropogenic emissions during this period. Rather, a long tail in March (more than 25 days of time lag) is seen at each of the four sites and is most evident at Barrow, Alert, and Zeppelin. These are European anthropogenic emissions that had been circulating in the Arctic troposphere. Their relative contributions are $10 \%$ at Barrow, $18 \%$ at Alert, and $13 \%$ at Zeppelin. Siberian anthropogenic contributions, mostly from natural gas flares (42\% at Alert and $62 \%$ at Zeppelin) in the WENR (Stohl et al., 2013; Qi et al., 2017a), have large impacts on BC at Alert and Zeppelin after 6-15 days of transport. Gas flaring contributions are relatively small at Denali $(\sim 3 \%)$ and Barrow $(\sim 7 \%)$ and negligible at Summit $(\sim 1 \%)$ because of the weak sensitivities (Sect. 4.2.1)

Overall, episodic, direct transport dominates anthropogenic contributions at Denali (out of the Arctic front, $87 \%$ ), while chronic, circumpolar transport dominates anthropogenic contributions at Alert (the furthest north in the Arctic of the five sites, $89 \%$ ). The two types of contributions are comparable at Barrow (direct: $42 \%$ ) and Zeppelin (direct: $52 \%$ ). BC concentration from direct transport events at Barrow $\left(12.9 \mathrm{ng} \mathrm{m}^{-3}\right)$ is more than 1 order of magnitude lower than that at Denali $\left(177.4 \mathrm{ng} \mathrm{m}^{-3}\right)$. This difference is largely explained by the strong transport barrier, i.e., the Arctic front at $\sim 66^{\circ} \mathrm{N}$ (Stohl, 2006 and references therein), which lies between and separates Denali $\left(63.7^{\circ} \mathrm{N}\right)$ and Barrow $\left(71.3^{\circ} \mathrm{N}\right)$. $\mathrm{BC}$ concentration at $750 \mathrm{hPa}$, above the Arctic front, over Barrow is more than a factor of 3 larger than that at the surface during 20-25 April (Fig. 7). Contribu- 


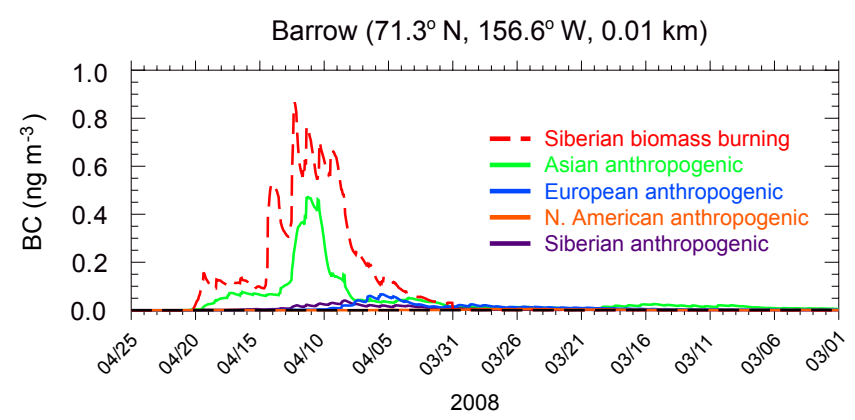

Figure 7. Same as Fig. $6 \mathrm{~b}$ but for $\mathrm{BC}$ at $750 \mathrm{hPa}$ above Barrow.

tions from both Asian anthropogenic sources and Siberian biomass burning emissions to $\mathrm{BC}$ at $750 \mathrm{hPa}$ at Barrow (Asian anthropogenic: $57.0 \mathrm{ng} \mathrm{g}^{-1}$; Siberian biomass burning: $119.8 \mathrm{ng} \mathrm{g}^{-1}$ ) are 4 times larger than those at the surface at Barrow (Asian anthropogenic: $13.6 \mathrm{ng} \mathrm{g}^{-1}$; Siberian biomass burning: $30.4 \mathrm{ng} \mathrm{g}^{-1}$ ) and are comparable to their contributions to Denali (Asian anthropogenic: $38.3 \mathrm{ng} \mathrm{g}^{-1}$; Siberian biomass burning: $137.8 \mathrm{ng} \mathrm{g}^{-1}$ ). The Arctic front also traps $\mathrm{BC}$ emitted within the front to the Arctic lower troposphere. This trapping is evident at Barrow; North American anthropogenic emissions are significant sources for BC at the surface $(13 \%)$ but negligible at $750 \mathrm{hPa}(1 \%)$. Zeppelin is strongly influenced by direct transport of natural gas flaring emissions in the WENR and European anthropogenic emissions. BC at Alert is also enhanced by direct transport from these flaring emissions but to a much lesser extent (a factor of 5 lower) compared with Zeppelin. In contrast, almost all biomass burning contributions (>97\%) are from direct transport events in April at the four sites.

BC at Summit shows remarkably different signatures of source types and source regions than that at the other four sites. This free tropospheric site experiences a large and persistent contribution from anthropogenic sources of BC emitted during 1 March-15 April in Asia, spanning timescales of 10-50 days. North American anthropogenic emissions take as little as 4 days (4-16 days) to impact BC at Summit because of the close proximity. Somewhat surprisingly, Summit is subject to comparable influences from European and North American anthropogenic emissions ( 20\%). Anthropogenic BC emitted during 8-15 April in Europe arrives at the site after 10-17 days of transport.

\subsection{Uncertainty analysis}

\subsubsection{Uncertainty associated with the temporal resolution of biomass burning emissions}

Open biomass burning emissions are known to have large day-to-day and diurnal variations (Giglio, 2007). It is conceivable that the temporal resolution of biomass burning emissions used in the model may introduce significant uncertainty in our source attribution. Here, we examine the sensi- tivity of BC at the five sites to temporal variation of Siberian biomass burning emissions and explore the implications of these variations on atmospheric transport of $\mathrm{BC}$ to the Arctic. Specifically, we use both monthly and 3-hourly biomass burning emission inventories (Sect. 3.1) to assess the abovementioned uncertainty. Figure 8 a shows both monthly and 3-hourly BC biomass burning emissions in Siberia during March-April 2008. Also overlaid is the adjoint sensitivity of Arctic surface BC (at the five sites) to the emissions. Biomass burning contributions to Arctic surface BC are thus the combined results of the spatiotemporal distribution of the emissions and the sensitivities (Sect. 3.2). Figure 8b shows the resulting contributions from Siberian biomass burning to mean BC concentrations on 20-25 April at the five sites. The 3hourly inventory results in more significant day-to-day and diurnal variations, as expected, and more acute episodic contributions (e.g., at Barrow from emissions during 9-10 and 13-15 April). In contrast, the monthly inventory leads to more broad and persistent contributions from emissions during 1-15 April, with more mesoscale variations. The temporal variation of contributions in April estimated from the monthly inventory generally follows the variation of sensitivities. Contribution maxima correspond to sensitivity maxima, such as the contribution peaks during 7-10 April at Barrow and during 8-11 April at Alert. Contributions estimated using the 3-hourly inventory also peak on the same days. Contributions in March are negligible because of very low biomass burning emissions. Overall, the 3-hourly inventory leads to weaker poleward transport of BC. For instance, the contribution is 50\% lower at Denali, 31-39\% lower at Barrow, Alert, and Zeppelin, and $6 \%$ lower at Summit. The lower contributions are because the much larger BC emissions after 12 April in the 3-hourly inventory have little effect on surface BC concentrations during 20-25 April, because they can hardly be transported to the Arctic surface during such a short time, shown as out of phase of the temporal variation of the 3-hourly inventory and the sensitivities at all sites (Fig. 8a). The resulting BC concentrations at Denali, Barrow, and Alert compare worse with observations, while the comparison is improved at Zeppelin and Summit.

\subsubsection{Uncertainty associated with wet scavenging}

We examine here the role of wet scavenging, a determining factor of BC loading in the Arctic (Huang et al., 2010b; Vignati et al., 2010; Liu et al., 2011; Browse et al., 2012; Qi et al., 2017a), on poleward transport of BC. A critical process that affects the wet scavenging of $\mathrm{BC}$ particles is WBF (Cozic et al., 2007; Henning et al., 2004). In a previous study, we have shown that WBF releases BC particles incorporated in cloud water drops back into interstitial air in mixed-phase clouds, and thereby strongly reduces BC scavenging efficiency and slows down subsequent wet scavenging (Qi et al., 2017b). Conversely, the absence of WBF leads to lower mean $\mathrm{BC}$ concentrations in surface air. To examine 
(a)
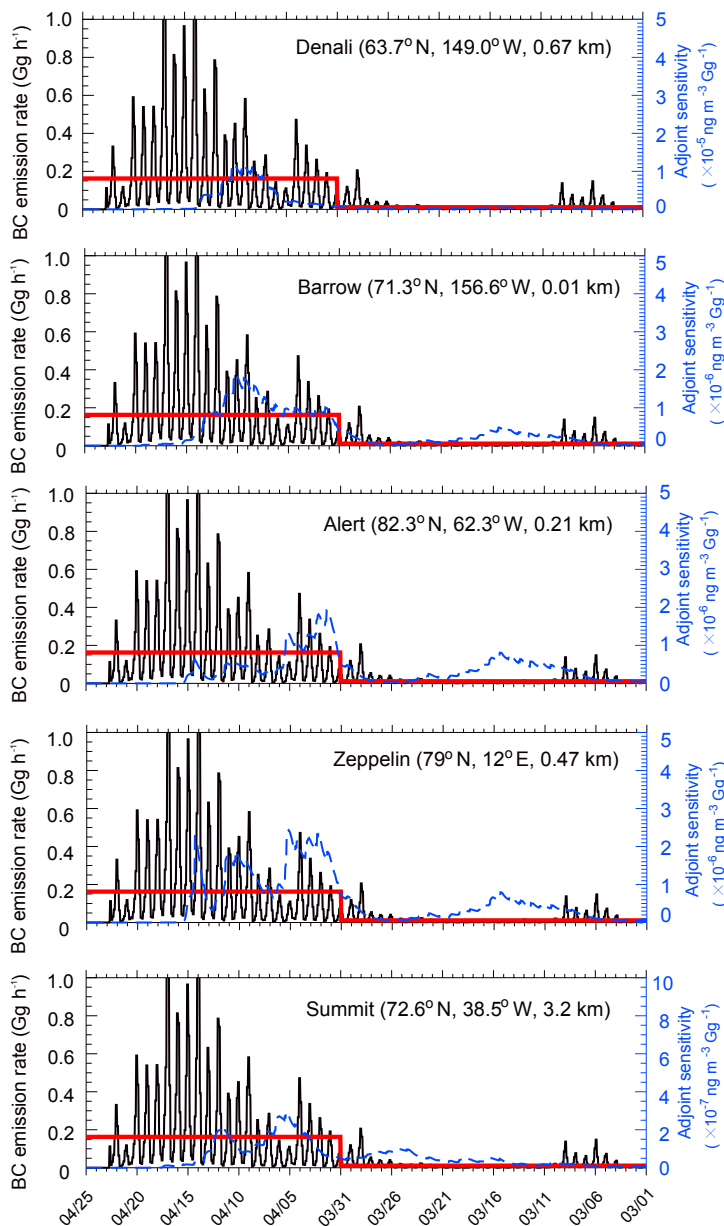

2008
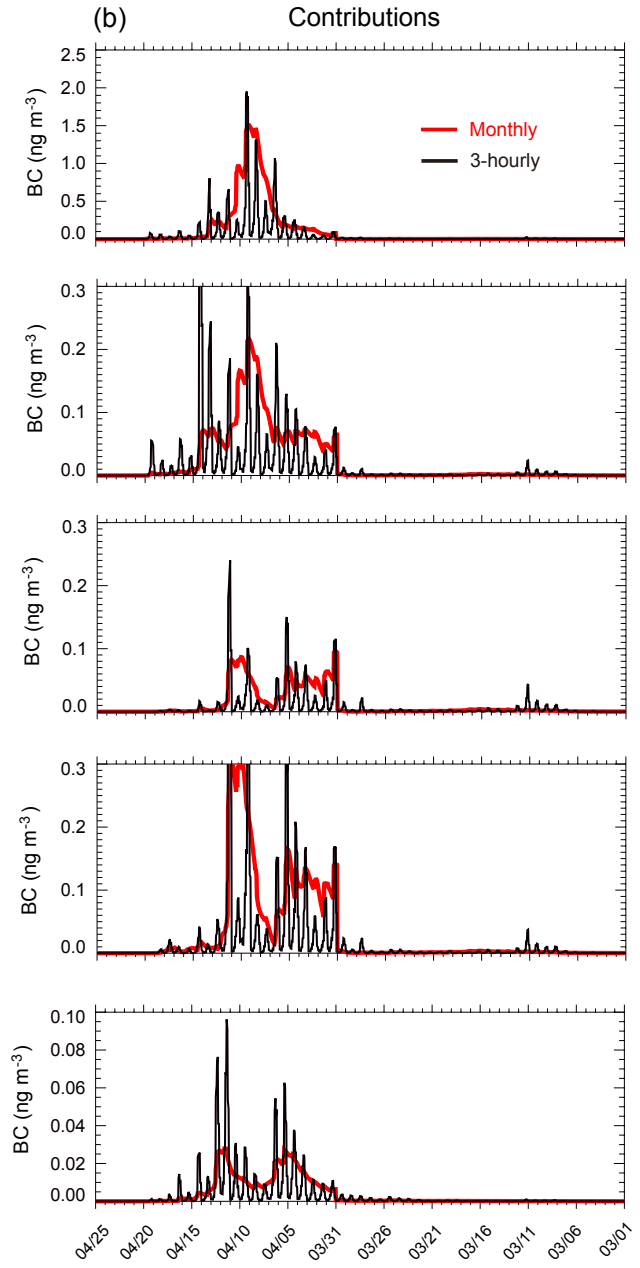

2008

Figure 8. (a) Biomass burning BC emission rates $\left(\mathrm{Gg} \mathrm{h}^{-1}\right.$, red - monthly, black - 3-hourly) in Siberia (see Fig. 2) for April 2008 and (b) contributions $\left(\mathrm{ng} \mathrm{m}^{-3}\right)$ to $\mathrm{BC}$ at the five sites from Siberian biomass burning emissions (red - monthly, black - 3-hourly) during 1 March25 April. Emission data are from the Global Fire Emissions Database version 3 (GFEDv3) inventory (Randerson et al., 2012). Adjoint sensitivities of mean BC during 20-25 April 2008 at the five sites (see Fig. 1) to Siberia biomass burning emissions are also shown (a, dashed blue).

the effect of WBF on Arctic surface BC, we conduct a simulation whereby WBF is turned off. A direct consequence of the absence of WBF is weaker sensitivities of Arctic BC to global emissions. Figure 9 shows the reductions of these sensitivities relative to the standard simulation (which includes WBF). In the absence of WBF, the sensitivities are lower by $10-90 \%$ for most regions. The resulting BC concentrations in surface air at the five sites are lower by $18-52 \%$. The discrepancies against observations with and without WBF at Denali are within $20 \%$. The negative discrepancy against observations is further exaggerated at Barrow and Alert (from $\sim-10 \%$ with $\mathrm{WBF}$ to $\sim-55 \%$ without $\mathrm{WBF}$ ), while the large positive discrepancies are reduced at Zeppelin (from $89 \%$ with WBF to $-10 \%$ without WBF) and Summit (from $65 \%$ with WBF to $-15 \%$ without WBF).
The absence of WBF results in inhomogeneous reduction of sensitivities. For Denali, Barrow, Alert, and Zeppelin, the reductions of sensitivities are larger in source regions far from the sites and smaller for emissions near the sites. The resulting relative contributions are higher from near-field regions, but lower from far-field regions. At Denali, for example, the WBF effect results in significantly larger reductions of sensitivities to emissions from Europe (50-70\%) than to those from the North American sector in the Arctic and the North Pacific (20-40\%). Consequently, the resulting relative contribution from North America is larger in the absence of WBF $(50 \%)$ than that with WBF included (43\%). Similarly, for Barrow, the relative contribution increases from 12 to $17 \%$ for North American emissions and from 49 to $51 \%$ for Siberian emissions in the absence of WBF, while the relative contributions decrease for other sources. For Alert and Zep- 


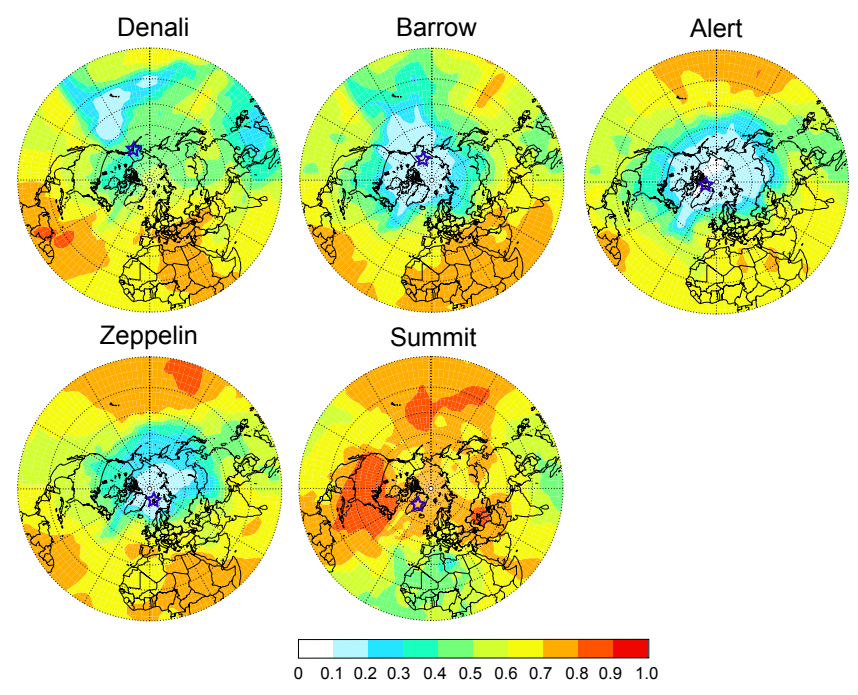

Figure 9. Reduction of adjoint sensitivities of $\mathrm{BC}$ concentration at selected Arctic sites (Fig. 1) to Northern Hemisphere emissions in the absence of WBF relative to standard simulation, averaged for the whole simulation period of 1 March-25 April 2008.

pelin, the relative contributions from proximate source region Siberia increase from 46 to $53 \%$ at Alert and from 66 to $72 \%$ at Zeppelin. This indicates that WBF strongly increases the poleward transport of BC from far field regions. For Summit, the reduction of sensitivity without WBF is more evenly distributed than other surface sites and the resulting relative contributions from different sources change marginally.

\subsubsection{Other uncertainties}

A large portion of $\mathrm{BC}$ in the Arctic is transported from lower latitudes via low-pressure systems, particularly the polar front (Stohl, 2006), which is considerably finer than the spatial resolution of GEOS-Chem used in this study ( $2^{\circ}$ latitude $\times 2.5^{\circ}$ longitude) and other global models. A recent study (Sato et al., 2016) found that a better representation of the vortex structure of the low-pressure and frontal systems using a finer horizontal resolution $(3.5 \mathrm{~km})$ in a global model enhanced the poleward transport of BC from Europe-Siberia, Asia, and North America, with relatively larger increase in Asia and smaller increase in the Europe-Siberia region. In addition, Ma et al. (2014) found that a 1 order of magnitude increase of simulated BC at Barrow from $160 \mathrm{~km}$ resolution simulation to $10 \mathrm{~km}$ resolution simulation is related to the filamentary structure of aerosol plumes from northeast Asia, which can only be resolved by the higher resolution. Thus, the coarse resolution of GEOS-Chem in this study might have overestimated the relative contribution from Europe and Siberia, while it underestimated the relative contribution from Asia.
GEOS-Chem generally captures the observed BC concentrations at Arctic surface, but the large positive bias at Zeppelin $(80 \%)$ and Summit $(60 \%)$ has some implications for the uncertainties of source apportionment. At Zeppelin, one of the possible reasons for the large positive bias is that the flaring emissions used in this study are probably too high because the emission factor used is much larger than the current field and lab measurements (Qi et al., 2017a). The resulting contribution from Russian anthropogenic sources to the Arctic surface is probably also biased high in this study. The other reason for the large positive bias of $\mathrm{BC}$ concentration at the two sites is the misrepresentation of the WBF versus riming effects based only on temperature or ice mass fraction. The uncertainties introduced by WBF are discussed in Sect. 4.3.2.

\section{Summary and conclusions}

This study identified sources of BC at surface sites outside Arctic front (Denali), inside the Arctic front (Barrow, Alert, and Zeppelin), and in the Arctic free troposphere (Summit) using a 3-D global chemical transport model GEOS-Chem with concentrations tagged by emission source regions at the continental scale in April 2008. We also identified sources and temporal variations of $\mathrm{BC}$ during a pollution episode at these five sites at $2^{\circ}$ latitude $\times 2.5^{\circ}$ longitude horizontal and hourly temporal resolution using the GEOS-Chem adjoint model.

The tagger tracer technique showed that the largest sources of BC in the Arctic in April 2008 were Asian anthropogenic sources (35-45\%) and Siberian biomass burning emissions (46-64\%). Adjoint sensitivity showed that, during a transport episode in 20-25 April, BC at Denali and Barrow in Alaska was most sensitive to ship emissions of $\mathrm{BC}$ in the $\mathrm{Pa}$ cific Ocean while BC at Alert and Zeppelin was most sensitive to emissions in the Arctic Circle and Eurasia. At Summit, in the free troposphere, $\mathrm{BC}$ was more sensitive to emissions at lower latitudes than those at higher latitudes.

The fine horizontal resolution of adjoint helped to identify forest fires in the southern Siberia-Lake Baikal area as the largest sources of biomass burning, accounting for more than $90 \%$ of total global biomass burning contributions to BC at the five receptor sites during 20-25 April 2008. The largest anthropogenic sources of BC at Denali and Barrow were local and regional emissions in Alaska. In addition, residential emissions from the Heilongjiang province in northeast China were a large anthropogenic source for Denali. For Alert and Zeppelin, the largest anthropogenic sources were gas flares in WENR. Anthropogenic sources (industrial and residential) in the Jing-Jin-Ji cluster of megacities and Shandong province in China were large sources $(\sim 10 \%)$ of $\mathrm{BC}$ at Barrow, Alert, and Zeppelin in the high Arctic.

Sources and source regions of $\mathrm{BC}$ in the springtime Arctic identified in this study were in broad agreement with previ- 
ous estimates. We found that the contribution from biomass burning was in the range of 5.2-55.1\%, in agreement with previous observations of the ratio of levoglucosan and $\mathrm{BC}$ (Yttri et al., 2014). Transport pathways were consistent with previously identified pathways of $\mathrm{BC}$ reaching the Arctic surface (Hirdman et al., 2010; Dutkiewicz et al., 2014) and the troposphere (e.g., Klonecki et al., 2003; Stohl, 2006; Wang et al., 2014). For instance, anthropogenic emissions from Siberia and Europe were transported to the Arctic through low-level transport (Klonecki et al., 2003; Stohl, 2006; Harrigan et al., 2011; Marelle et al., 2015), while anthropogenic emissions from Asia and biomass burning emissions from south Asia were uplifted in source regions and entered the Arctic through the middle and upper troposphere (Matsui et al., 2011; Wang et al., 2014; Liu et al., 2015). The timescales for the transport estimated in this study were also consistent with previous estimates (Stohl, 2006; Harrigan et al., 2011). Asian emissions took 12-17 days to reach the Arctic surface. European, Russian, and North American emissions took 09 days because of the closeness to the Arctic.

In contrast with the previous estimates, we found that a large portion of Asian contribution was in the form of chronic pollution on a timescale of 1-2 months, which is not captured by the 5- or 10-day back trajectories. The fine temporal resolution of contribution estimated using the adjoint method differentiated the contributions of episodic, direct transport from that of chronic, circumpolar transport. Our results suggested that even during a strong pollution episode, direct transport accounted for half of the contribution at most (42\% at Barrow, $52 \%$ at Zeppelin, and $11 \%$ at Alert). The chronic, circumpolar transport of $\mathrm{BC}$ was the largest contributor to $\mathrm{BC}$ at the surface. A large fraction of the Asian contribution was from the chronic circumpolar transport $(\sim 60 \%$ at Barrow and $\sim 100 \%$ at Alert and Zeppelin). The long direct transport timescale ( $>12$ days) and the large contribution from chronic pollution suggested that Asian contribution to surface $\mathrm{BC}$ in the Arctic was probably strongly underestimated by previous studies that were based on 5- or 10-day trajectory analysis.

Source attribution of Arctic surface BC using the adjoint method was associated with uncertainties from all processes, including emissions, transport, aging, and deposition. We found that using a 3-hourly temporal resolution of biomass burning emissions reduced BC concentration strongly at Denali $(\sim 50 \%)$, moderately $(\sim 30 \%)$ at Barrow, Alert, and Zeppelin, and marginally $(6 \%)$ at Summit. Finer resolution did not affect global sensitivity. The decrease of contribution resulted from the emissions and sensitivities being out of phase. BC concentrations at the five sites were lower by 35$52 \%$ without $\mathrm{WBF}$, resulting from a reduction of sensitivities to global emissions. Without WBF, the sensitivity decreased more in regions far from the sites than those near the sites for Denali, Barrow, Alert, and Zeppelin. Thus, the relative contribution from proximate sources increased in the absence of WBF. This indicated that WBF strongly increased the pole- ward transport from lower latitudes. For Summit, the change of the relative contribution from different regions without WBF was negligible.

Data availability. The data used in this study are available from the corresponding author upon request (qiling0420@gmail.com).

\section{The Supplement related to this article is available online at https://doi.org/10.5194/acp-17-9697-2017-supplement.}

Competing interests. The authors declare that they have no conflict of interest.

Acknowledgements. This study was funded by NASA grant NNX14AF11G from the Atmospheric Chemistry Modeling and Analysis Program (ACMAP) and by a grant from the US Environmental Protection Agency's Science to Achieve Results (STAR) program. Although the research described in the article has been funded completely or in part by the US Environmental Protection Agency's STAR program through grant R835037, it has not been subjected to any EPA review and therefore does not necessarily reflect the views of the Agency, and no official endorsement should be inferred. We would also like to thank the Global Monitoring Division at the NOAA Earth System Research Laboratory, the Atmospheric Science and Technology Directorate at Environment Canada, and SFT Norway for providing the data. The Swedish Environmental Protection Agency and the Swedish Research Council have sponsored BC measurements at Zeppelin.

Edited by: Xiaohong Liu

Reviewed by: three anonymous referees

\section{References}

AMAP: Snow, Water, Ice and Permafrost in the Arctic (SWIPA), Climate Change and the Cryosphere, Arctic Monitoring and Assessment Programme (AMAP), Oslo, Narayana Press, Gylling, Denmark, ISBN-13: 978-82-7971-073-8, 538 pp., 2011.

Bond, T. C., Bhardwaj, E., Dong, R., Jogani, R., Jung, S. K., Roden, C., Streets, D. G., and Trautmann, N. M.: Historical emissions of black and organic carbon aerosol from energy-related combustion, 1850-2000, Global Biogeochem. Cy., 21, GB2018, https://doi.org/10.1029/2006gb002840, 2007.

Bond, T. C., Doherty, S. J., Fahey, D. W., Forster, P. M., Berntsen, T., DeAngelo, B. J., Flanner, M. G., Ghan, S., Kärcher, B., Koch, D., Kinne, S., Kondo, Y., Quinn, P. K., Sarofim, M. C., Schultz, M. G., Schulz, M., Venkataraman, C., Zhang, H., Zhang, S., Bellouin, N., Guttikunda, S. K., Hopke, P. K., Jacobson, M. Z., Kaiser, J. W., Klimont, Z., Lohmann, U., Schwarz, J. P., Shindell, D., Storelvmo, T., Warren, S. G., and Zender, C. S.: Bounding the role of black carbon in the climate system: A scientific assessment, J. Geophys. Res.-Atmos., 118, 5380-5552, https://doi.org/10.1002/jgrd.50171, 2013. 
Bourgeois, Q. and Bey, I.: Pollution transport efficiency toward the Arctic: Sensitivity to aerosol scavenging and source regions, J. Geophys. Res.-Atmos., 116, 5380-5552, https://doi.org/10.1029/2010jd015096, 2011.

Brock, C. A., Cozic, J., Bahreini, R., Froyd, K. D., Middlebrook, A. M., McComiskey, A., Brioude, J., Cooper, O. R., Stohl, A., Aikin, K. C., de Gouw, J. A., Fahey, D. W., Ferrare, R. A., Gao, R.-S., Gore, W., Holloway, J. S., Hübler, G., Jefferson, A., Lack, D. A., Lance, S., Moore, R. H., Murphy, D. M., Nenes, A., Novelli, P. C., Nowak, J. B., Ogren, J. A., Peischl, J., Pierce, R. B., Pilewskie, P., Quinn, P. K., Ryerson, T. B., Schmidt, K. S., Schwarz, J. P., Sodemann, H., Spackman, J. R., Stark, H., Thomson, D. S., Thornberry, T., Veres, P., Watts, L. A., Warneke, C., and Wollny, A. G.: Characteristics, sources, and transport of aerosols measured in spring 2008 during the aerosol, radiation, and cloud processes affecting Arctic Climate (ARCPAC) Project, Atmos. Chem. Phys., 11, 2423 2453, https://doi.org/10.5194/acp-11-2423-2011, 2011.

Browse, J., Carslaw, K. S., Arnold, S. R., Pringle, K., and Boucher, O.: The scavenging processes controlling the seasonal cycle in Arctic sulphate and black carbon aerosol, Atmos. Chem. Phys., 12, 6775-6798, https://doi.org/10.5194/acp12-6775-2012, 2012.

Cozic, J., Verheggen, B., Mertes, S., Connolly, P., Bower, K., Petzold, A., Baltensperger, U., and Weingartner, E.: Scavenging of black carbon in mixed phase clouds at the high alpine site Jungfraujoch, Atmos. Chem. Phys., 7, 1797-1807, https://doi.org/10.5194/acp-7-1797-2007, 2007.

Dutkiewicz, V. A., DeJulio, A. M., Ahmed, T., Laing, J., Hopke, P. K., Skeie, R. B., Viisanen, Y., Paatero, J., and Husain, L.: Fortyseven years of weekly atmospheric black carbon measurements in the Finnish Arctic: Decrease in black carbon with declining emissions, J. Geophys. Res.-Atmos., 119, 7667-7683, 2014.

Eleftheriadis, K., Vratolis, S., and Nyeki, S.: Aerosol black carbon in the European Arctic: Measurements at Zeppelin station, Ny-Ålesund, Svalbard from 1998-2007, Geophys. Res. Lett., 36, L02809, https://doi.org/10.1029/2008g1035741, 2009.

Flanner, M. G.: Arctic climate sensitivity to local black carbon, J. Geophys. Res.-Atmos., 118, 1840-1851, https://doi.org/10.1002/jgrd.50176, 2013.

Flannigan, M. D., Krawchuk, M. A., de Groot, W. J., Wotton, B. M., and Gowman, L. M.: Implications of changing climate for global wildland fire, Int. J. Wildland Fire, 18, 483-507, 2009.

Frossard, A. A., Shaw, P. M., Russell, L. M., Kroll, J. H., Canagaratna, M. R., Worsnop, D. R., Quinn, P. K., and Bates, T. S.: Springtime Arctic haze contributions of submicron organic particles from European and Asian combustion sources, J. Geophys. Res.-Atmos., 116, D05205, https://doi.org/10.1029/2010JD015178, 2011.

Fu, T.-M., Cao, J. J., Zhang, X. Y., Lee, S. C., Zhang, Q., Han, Y. M., Qu, W. J., Han, Z., Zhang, R., Wang, Y. X., Chen, D., and Henze, D. K.: Carbonaceous aerosols in China: top-down constraints on primary sources and estimation of secondary contribution, Atmos. Chem. Phys., 12, 2725-2746, https://doi.org/10.5194/acp12-2725-2012, 2012.

Fuelberg, H. E., Harrigan, D. L., and Sessions, W.: A meteorological overview of the ARCTAS 2008 mission, Atmos. Chem. Phys., 10, 817-842, https://doi.org/10.5194/acp-10-817-2010, 2010 .
Giglio, L., Kendall, J., and Mack, R.: A multi-year active fire dataset for the tropics derived from the TRMM VIRS, Int. J. Remote Sens., 24, 4505-4525, 2003.

Giglio, L.: Characterization of the tropical diurnal fire cycle using VIRS and MODIS observations, Remote Sens. Environ., 108, 407-421, 2007.

Gou, T. and Sandu, A.: Continuous versus discrete advection adjoints in chemical data assimilation with CMAQ, Atmos. Environ., 45, 4868-4881, 2011.

Hakami, A., Henze, D. K., Seinfeld, J. H., Singh, K., Sandu, A., Kim, S., Byun, D., and Li, Q.: The adjoint of CMAQ, Environ. Sci. Technol., 41, 7807-7817, 2007.

Harrigan, D. L., Fuelberg, H. E., Simpson, I. J., Blake, D. R., Carmichael, G. R., and Diskin, G. S.: Anthropogenic emissions during Arctas-A: mean transport characteristics and regional case studies, Atmos. Chem. Phys., 11, 8677-8701, https://doi.org/10.5194/acp-11-8677-2011, 2011.

Henning, S.: Aerosol partitioning in natural mixedphase clouds, Geophys. Res. Lett., 31, L06101, https://doi.org/10.1029/2003gl019025, 2004.

Henze, D. K., Hakami, A., and Seinfeld, J. H.: Development of the adjoint of GEOS-Chem, Atmos. Chem. Phys., 7, 2413-2433, https://doi.org/10.5194/acp-7-2413-2007, 2007.

Henze, D. K., Seinfeld, J. H., and Shindell, D. T.: Inverse modeling and mapping US air quality influences of inorganic $\mathrm{PM}_{2.5}$ precursor emissions using the adjoint of GEOS-Chem, Atmos. Chem. Phys., 9, 5877-5903, https://doi.org/10.5194/acp-9-58772009, 2009.

Henze, D. K., Shindell, D. T., Akhtar, F., Spurr, R. J., Pinder, R. W., Loughlin, D., Kopacz, M., Singh, K., and Shim, C.: Spatially refined aerosol direct radiative forcing efficiencies, Environ. Sci. Technol., 46, 9511-9518, 2012.

Hirdman, D., Sodemann, H., Eckhardt, S., Burkhart, J. F., Jefferson, A., Mefford, T., Quinn, P. K., Sharma, S., Ström, J., and Stohl, A.: Source identification of short-lived air pollutants in the Arctic using statistical analysis of measurement data and particle dispersion model output, Atmos. Chem. Phys., 10, 669-693, https://doi.org/10.5194/acp-10-669-2010, 2010.

Huang, L., Gong, S., Jia, C., and Lavoué, D.: Relative contributions of anthropogenic emissions to black carbon aerosol in the Arctic, J. Geophys. Res.-Atmos., 115, D19208,https://doi.org/10.1029/2009JD013592, 2010a.

Huang, L., Gong, S., Jia, C., and Lavoué, D.: Importance of deposition processes in simulating the seasonality of the Arctic black carbon aerosol, J. Geophys. Res.-Atmos., 115, D17207, https://doi.org/10.1029/2009JD013478, 2010b.

Jacob, D. J., Crawford, J. H., Maring, H., Clarke, A. D., Dibb, J. E., Emmons, L. K., Ferrare, R. A., Hostetler, C. A., Russell, P. B., Singh, H. B., Thompson, A. M., Shaw, G. E., McCauley, E., Pederson, J. R., and Fisher, J. A.: The Arctic Research of the Composition of the Troposphere from Aircraft and Satellites (ARCTAS) mission: design, execution, and first results, Atmos. Chem. Phys., 10, 5191-5212, https://doi.org/10.5194/acp10-5191-2010, 2010.

Klonecki, A., Hess, P., Emmons, L., Smith, L., Orlando, J., and Blake, D.: Seasonal changes in the transport of pollutants into the Arctic troposphere-model study, J. Geophys. Res.-Atmos., 108, 8367, https://doi.org/10.1029/2002JD002199, 2003. 
Koch, D. and Hansen, J.: Distant origins of Arctic black carbon: a Goddard Institute for Space Studies ModelE experiment, J. Geophys. Res.-Atmos., 110, D04204, https://doi.org/10.1029/2004JD005296, 2005.

Kopacz, M., Jacob, D. J., Henze, D. K., Heald, C. L., Streets, D. G., and Zhang, Q.: Comparison of adjoint and analytical Bayesian inversion methods for constraining Asian sources of carbon monoxide using satellite (MOPITT) measurements of CO columns, J. Geophys. Res.-Atmos., 114, D04305, https://doi.org/10.1029/2007JD009264, 2009.

Kopacz, M., Jacob, D. J., Fisher, J. A., Logan, J. A., Zhang, L., Megretskaia, I. A., Yantosca, R. M., Singh, K., Henze, D. K., Burrows, J. P., Buchwitz, M., Khlystova, I., McMillan, W. W., Gille, J. C., Edwards, D. P., Eldering, A., Thouret, V., and Nedelec, P.: Global estimates of CO sources with high resolution by adjoint inversion of multiple satellite datasets (MOPITT, AIRS, SCIAMACHY, TES), Atmos. Chem. Phys., 10, 855-876, https://doi.org/10.5194/acp-10-855-2010, 2010.

Kopacz, M., Mauzerall, D. L., Wang, J., Leibensperger, E. M., Henze, D. K., and Singh, K.: Origin and radiative forcing of black carbon transported to the Himalayas and Tibetan Plateau, Atmos. Chem. Phys., 11, 2837-2852, https://doi.org/10.5194/acp-11-2837-2011, 2011.

Liu, D., Quennehen, B., Darbyshire, E., Allan, J. D., Williams, P. I., Taylor, J. W., Bauguitte, S. J.-B., Flynn, M. J., Lowe, D., Gallagher, M. W., Bower, K. N., Choularton, T. W., and Coe, H.: The importance of Asia as a source of black carbon to the European Arctic during springtime 2013, Atmos. Chem. Phys., 15, 1153711555, https://doi.org/10.5194/acp-15-11537-2015, 2015.

Liu, J., Fan, S., Horowitz, L. W., and Levy, H.: Evaluation of factors controlling long-range transport of black carbon to the Arctic, J. Geophys. Res., 116, D04307, https://doi.org/10.1029/2010jd015145, 2011.

Liu, Z. and Sandu, A.: On the properties of discrete adjoints of numerical methods for the advection equation, Int. J. Numer. Meth. Fl., 56, 769-803, https://doi.org/10.1002/fld.1547, 2008.

Liu, Z., Yang, J., Chang, Y., Weisberg, P. J., and He, H. S.: Spatial patterns and drivers of fire occurrence and its future trend under climate change in a boreal forest of Northeast China, Glob. Change Biol., 18, 2041-2056, 2012.

Ma, P. L., Gattiker, J. R., Liu, X., and Rasch, P. J.: A novel approach for determining source-receptor relationships in model simulations: A case study of black carbon transport in Northern Hemisphere winter, Environ. Res. Lett., 8, 02042, https://doi.org/10.1088/1748-9326/8/2/024042, 2013.

Ma, P.-L., Rasch, P. J., Fast, J. D., Easter, R. C., Gustafson Jr., W. I., Liu, X., Ghan, S. J., and Singh, B.: Assessing the CAM5 physics suite in the WRF-Chem model: implementation, resolution sensitivity, and a first evaluation for a regional case study, Geosci. Model Dev., 7, 755-778, https://doi.org/10.5194/gmd-7755-2014, 2014.

Mao, Y. H., Li, Q. B., Chen, D., Zhang, L., Hao, W.-M., and Liou, K.-N.: Top-down estimates of biomass burning emissions of black carbon in the Western United States, Atmos. Chem. Phys., 14, 7195-7211, https://doi.org/10.5194/acp-147195-2014, 2014.

Marelle, L., Raut, J.-C., Thomas, J. L., Law, K. S., Quennehen, B., Ancellet, G., Pelon, J., Schwarzenboeck, A., and Fast, J. D.: Transport of anthropogenic and biomass burning aerosols from Europe to the Arctic during spring 2008, Atmos. Chem. Phys., 15, 3831-3850, https://doi.org/10.5194/acp15-3831-2015, 2015.

Matsui, H., Kondo, Y., Moteki, N., Takegawa, N., Sahu, L., Zhao, Y., Fuelberg, H., Sessions, W., Diskin, G., and Blake, D.: Seasonal variation of the transport of black carbon aerosol from the Asian continent to the Arctic during the ARCTAS aircraft campaign, J. Geophys. Res.-Atmos., 116, D05202, https://doi.org/10.1029/2010JD015067, 2011.

Mu, M., Randerson, J. T., van der Werf, G. R., Giglio, L., Kasibhatla, P., Morton, D., Collatz, G. J., DeFries, R. S., Hyer, E. J., Prins, E. M., Griffith, D. W. T., Wunch, D., Toon, G. C., Sherlock, V., and Wennberg, P. O.: Daily and 3-hourly variability in global fire emissions and consequences for atmospheric model predictions of carbon monoxide, J. Geophys. Res.-Atmos., 116, D24303, https://doi.org/10.1029/2011jd016245, 2011.

Nester, K. and Panitz, H.-J.: Sensitivity analysis by the adjoint chemistry transport model DRAISfor an episode in the Berlin Ozone (BERLIOZ) experiment, Atmos. Chem. Phys., 6, 20912106, https://doi.org/10.5194/acp-6-2091-2006, 2006.

Park, R. J., Jacob, D. J., Chin, M., and Martin, R. V.: Sources of carbonaceous aerosols over the United States and implications for natural visibility, J. Geophys. Res.-Atmos., 108, 4355, https://doi.org/10.1029/2002jd003190, 2003.

Park, R. J., Jacob, D. J., Palmer, P. I., Clarke, A. D., Weber, R. J., Zondlo, M. A., Eisele, F. L., Bandy, A. R., Thornton, D. C., Sachse, G. W., and Bond, T. C.: Export efficiency of black carbon aerosol in continental outflow: Global implications, J. Geophys. Res.-Atmos., 110, D11205, https://doi.org/10.1029/2004jd005432, 2005.

Polissar, A. V., Hopke, P. K., and Harris, J. M.: Source regions for atmospheric aerosol measured at Barrow, Alaska, Environ. Sci. Technol., 35, 4214-4226, 2001.

Prins, E. M., Feltz, J. M., Menzel, W. P., and Ward, D. E.: An overview of GOES-8 diurnal fire and smoke results for SCAR-B and 1995 fire season in South America, J. Geophys. Res.-Atmos., 103, 31821-31835, 1998.

Qi, L., Li, Q., Li, Y., and He, C.: Factors controlling black carbon distribution in the Arctic, Atmos. Chem. Phys., 17, 1037-1059, https://doi.org/10.5194/acp-17-1037-2017, 2017a.

Qi, L., Li, Q., He, C., Wang, X., and Huang, J.: Effects of the Wegener-Bergeron-Findeisen process on global black carbon distribution, Atmos. Chem. Phys., 17, 7459-7479, https://doi.org/10.5194/acp-17-7459-2017, $2017 \mathrm{~b}$.

Qin, Y. and Xie, S. D.: Spatial and temporal variation of anthropogenic black carbon emissions in China for the period 1980-2009, Atmos. Chem. Phys., 12, 4825-4841, https://doi.org/10.5194/acp-12-4825-2012, 2012.

Quinn, P. K., Bates, T. S., Baum, E., Doubleday, N., Fiore, A. M., Flanner, M., Fridlind, A., Garrett, T. J., Koch, D., Menon, S., Shindell, D., Stohl, A., and Warren, S. G.: Shortlived pollutants in the Arctic: their climate impact and possible mitigation strategies, Atmos. Chem. Phys., 8, 1723-1735, https://doi.org/10.5194/acp-8-1723-2008, 2008.

Randerson, J. T., Chen, Y., van der Werf, G. R., Rogers, B. M., and Morton, D. C.: Global burned area and biomass burning emissions from small fires, J. Geophys. Res.-Biogeo., 117, G04012, https://doi.org/10.1029/2012jg002128, 2012. 
Sand, M., Berntsen, T. K., Kay, J. E., Lamarque, J. F., Seland, $\varnothing$., and Kirkevåg, A.: The Arctic response to remote and local forcing of black carbon, Atmos. Chem. Phys., 13, 211-224, https://doi.org/10.5194/acp-13-211-2013, 2013.

Sand, M., Berntsen, T., von Salzen, K., Flanner, M., Langner, J., and Victor, D.: Response of Arctic temperature to changes in emissions of short-lived climate forcers, Nature Climate Change, 6 , 286-289, 2015.

Sato, Y., Miura, H., Yashiro, H., Goto, D., Takemura, T., Tomita, H., and Nkajima, T.: Unrealistically pristine air in the Arctic produced by current global scale models, Scientific Reports, 6 , 26561, https://doi.org/10.1038/srep26561, 2016.

Sharma, S., Lavoué, D., Cachier, H., Barrie, L. A., and Gong, S. L.: Long-term trends of the black carbon concentrations in the Canadian Arctic, J. Geophys. Res.-Atmos., 109, D15203, https://doi.org/10.1029/2003jd004331, 2004.

Sharma, S., Andrews, E., Barrie, L. A., Ogren, J. A., and Lavoué, D.: Variations and sources of the equivalent black carbon in the high Arctic revealed by long-term observations at Alert and Barrow: 1989-2003, J. Geophys. Res.-Atmos., 111, D14208, https://doi.org/10.1029/2005jd006581, 2006.

Sharma, S., Ishizawa, M., Chan, D., Lavoué, D., Andrews, E., Eleftheriadis, K., and Maksyutov, S.: 16-year simulation of Arctic black carbon: Transport, source contribution, and sensitivity analysis on deposition, J. Geophys. Res.-Atmos., 118, 943-964, https://doi.org/10.1029/2012jd017774, 2013.

Shaw, P., Russell, L., Jefferson, A., and Quinn, P.: Arctic organic aerosol measurements show particles from mixed combustion in spring haze and from frost flowers in winter, Geophys. Res. Lett., 37, L10803, https://doi.org/10.1029/2010GL042831, 2010.

Shindell, D. T., Chin, M., Dentener, F., Doherty, R. M., Faluvegi, G., Fiore, A. M., Hess, P., Koch, D. M., MacKenzie, I. A., Sanderson, M. G., Schultz, M. G., Schulz, M., Stevenson, D. S., Teich, H., Textor, C., Wild, O., Bergmann, D. J., Bey, I., Bian, H., Cuvelier, C., Duncan, B. N., Folberth, G., Horowitz, L. W., Jonson, J., Kaminski, J. W., Marmer, E., Park, R., Pringle, K. J., Schroeder, S., Szopa, S., Takemura, T., Zeng, G., Keating, T. J., and Zuber, A.: A multi-model assessment of pollution transport to the Arctic, Atmos. Chem. Phys., 8, 5353-5372, https://doi.org/10.5194/acp-8-5353-2008, 2008.

Shindell, D. and Faluvegi, G.: Climate response to regional radiative forcing during the twentieth century, Nat. Geosci., 2, 294-300, 2009.

Soja, A. J., Tchebakova, N. M., French, N. H., Flannigan, M. D., Shugart, H. H., Stocks, B. J., Sukhinin, A. I., Parfenova, E., Chapin, F. S., and Stackhouse, P. W.: Climate-induced boreal forest change: predictions versus current observations, Global Planet. Change, 56, 274-296, 2007.

Stohl, A.: Characteristics of atmospheric transport into the Arctic troposphere, J. Geophys. Res.-Atmos., 111, D11306, https://doi.org/10.1029/2005jd006888, 2006.

Stohl, A., Berg, T., Burkhart, J. F., Fjæraa, A. M., Forster, C., Herber, A., Hov, Ø., Lunder, C., McMillan, W. W., Oltmans, S., Shiobara, M., Simpson, D., Solberg, S., Stebel, K., Ström, J., Tørseth, K., Treffeisen, R., Virkkunen, K., and Yttri, K. E.: Arctic smoke - record high air pollution levels in the European Arctic due to agricultural fires in Eastern Europe in spring 2006, Atmos. Chem. Phys., 7, 511-534, https://doi.org/10.5194/acp-7511-2007, 2007.
Stohl, A., Klimont, Z., Eckhardt, S., Kupiainen, K., Shevchenko, V. P., Kopeikin, V. M., and Novigatsky, A. N.: Black carbon in the Arctic: the underestimated role of gas flaring and residential combustion emissions, Atmos. Chem. Phys., 13, 8833-8855, https://doi.org/10.5194/acp-13-8833-2013, 2013.

Thuburn, J. and Haine, T. W.: Adjoints of nonoscillatory advection schemes, J. Comput. Phys., 171, 616-631, 2001.

U.S. EIA: State Electricity Profiles 2008, Table 2, p. 7, DOE/EIA0348(01)/2, 2010.

U.S. EIA: Alaska State Energy Profile, available at: http://www. eia.gov/state/print.cfm?sid=AK\# (last access: 10 August 2017), 2016.

Vignati, E., Karl, M., Krol, M., Wilson, J., Stier, P., and Cavalli, F.: Sources of uncertainties in modelling black carbon at the global scale, Atmos. Chem. Phys., 10, 2595-2611, https://doi.org/10.5194/acp-10-2595-2010, 2010.

Walker, T., Jones, D., Parrington, M., Henze, D., Murray, L., Bottenheim, J., Anlauf, K., Worden, J., Bowman, K., and Shim, C.: Impacts of midlatitude precursor emissions and local photochemistry on ozone abundances in the Arctic, J. Geophys. Res.Atmos., 117, D01305, https://doi.org/10.1029/2011JD016370, 2012.

Wang, H., Rasch, P. J., Easter, R. C., Singh, B., Zhang, R., Ma, P. L., Qian, Y., Ghan, S. J., and Beagley, N.: Using an explicit emission tagging method in global modeling of source-receptor relationships for black carbon in the Arctic: Variations, sources, and transport pathways, J. Geophys. Res.-Atmos., 119, 1288812909, , 2014.

Wang, Q., Jacob, D. J., Fisher, J. A., Mao, J., Leibensperger, E. M., Carouge, C. C., Le Sager, P., Kondo, Y., Jimenez, J. L., Cubison, M. J., and Doherty, S. J.: Sources of carbonaceous aerosols and deposited black carbon in the Arctic in winter-spring: implications for radiative forcing, Atmos. Chem. Phys., 11, 1245312473, https://doi.org/10.5194/acp-11-12453-2011, 2011.

Wang, R., Tao, S., Wang, W., Liu, J., Shen, H., Shen, G., Wang, B., Liu, X., Li, W., and Huang, Y.: Black carbon emissions in China from 1949 to 2050, Environ. Sci. Technol., 46, 7595-7603, 2012.

Warneke, C., Bahreini, R., Brioude, J., Brock, C., De Gouw, J., Fahey, D., Froyd, K., Holloway, J., Middlebrook, A., and Miller, L.: Biomass burning in Siberia and Kazakhstan as an important source for haze over the Alaskan Arctic in April 2008, Geophys. Res. Lett., 36, L02813, https://doi.org/10.1029/2008GL036194, 2009.

Warneke, C., Froyd, K., Brioude, J., Bahreini, R., Brock, C., Cozic, J., De Gouw, J., Fahey, D., Ferrare, R., and Holloway, J.: An important contribution to springtime Arctic aerosol from biomass burning in Russia, Geophys. Res. Lett., 37, L01801, https://doi.org/10.1029/2009GL041816, 2010.

Wesely, M. L.: Parameterization of surface resistances to gaseous dry deposition in regional-scale numerical models, Atmos. Environ., 23, 1293-1304, https://doi.org/10.1016/00046981(89)90153-4, 1989.

Wotton, B. M., Nock, C. A., and Flannigan, M. D.: Forest fire occurrence and climate change in Canada, Int. J. Wildland Fire, 19, 253-271, 2010.

Yttri, K. E., Lund Myhre, C., Eckhardt, S., Fiebig, M., Dye, C., Hirdman, D., Ström, J., Klimont, Z., and Stohl, A.: Quantifying black carbon from biomass burning by means of levoglucosan - a one-year time series at the Arctic observatory Zeppelin, At- 
mos. Chem. Phys., 14, 6427-6442, https://doi.org/10.5194/acp14-6427-2014, 2014.

Zhang, L., Gong, S., Padro, J., and Barrie, L.: A size-segregated particle dry deposition scheme for an atmospheric aerosol module, Atmos. Environ., 35, 549-560, https://doi.org/10.1016/S13522310(00)00326-5, 2001.

Zhang, L., Jacob, D. J., Kopacz, M., Henze, D. K., Singh, K., and Jaffe, D. A.: Intercontinental source attribution of ozone pollution at western US sites using an adjoint method, Geophys. Res. Lett., 36, L11810, https://doi.org/10.1029/2009GL037950, 2009.

Zhang, Q., Streets, D. G., Carmichael, G. R., He, K. B., Huo, H., Kannari, A., Klimont, Z., Park, I. S., Reddy, S., Fu, J. S., Chen, D., Duan, L., Lei, Y., Wang, L. T., and Yao, Z. L.: Asian emissions in 2006 for the NASA INTEX-B mission, Atmos. Chem. Phys., 9, 5131-5153, https://doi.org/10.5194/acp-9-5131-2009, 2009.
Zhang, L., Liu, L., Zhao, Y., Gong, S., Zhang, X., Henze, D. K., Capps, S. L., Fu, T.-M., Zhang, Q., and Wang, Y.: Source attribution of particulate matter pollution over North China with the adjoint method, Environ. Res. Lett., 10, 084011, https://doi.org/10.1088/1748-9326/10/8/084011, 2015a.

Zhang, L., Henze, D. K., Grell, G. A., Carmichael, G. R., Bousserez, N., Zhang, Q., Torres, O., Ahn, C., Lu, Z., Cao, J., and Mao, Y.: Constraining black carbon aerosol over Asia using OMI aerosol absorption optical depth and the adjoint of GEOS-Chem, Atmos. Chem. Phys., 15, 10281-10308, https://doi.org/10.5194/acp-1510281-2015, 2015. 